\title{
Alpha-Casein as a Molecular Chaperone
}

\author{
Teresa Treweek
}

Additional information is available at the end of the chapter

http://dx.doi.org/10.5772/48348

\section{Introduction}

The caseins are a heterogeneous group of dairy proteins constituting $80 \%$ of the protein content of bovine milk. The operational definition of casein is that proportion of total milk protein which precipitates on acidification of milk to a $\mathrm{pH}$ value of 4.6 [1]. The remaining dairy proteins, known collectively as whey proteins, do not precipitate. Caseins are synthesised in the mammary gland and are found nowhere else among the plant and animal kingdoms [2]. The casein family of proteins comprises $\alpha-, \beta$ - and $\kappa$-caseins, all with little sequence homology [3]. As their primary function is nutritional, binding large amounts of calcium, zinc and other biologically important metals, amino acid substitutions or deletions have little impact on function. The caseins also lack well-defined structure and as a result their amino acid sequence is less critical to function than in many 'classic' globular proteins. As a result, the caseins are one of the most evolutionarily divergent protein families characterised in mammals [2]. Alpha-casein, also known as $\alpha$ s-casein, is in fact two distinct gene products, $\alpha_{51}$ - and $\alpha_{s 2}$-casein, with the ' $S$ ' denoting a sensitivity to calcium. Of all the caseins, $\alpha$ s1- and $\beta$-casein are predominant in bovine milk, representing 37 and $35 \%$ of whole casein respectively, whereas $\alpha_{\mathrm{s} 2}$ - and $\kappa$-casein make up 10 and $12 \%$ of whole casein, respectively [2].

\subsection{Key structural features of the casein proteins}

The casein proteins are important nutritionally not just because of their high phosphate content which allows them to bind significant quantities of calcium, but because they are high in lysine.

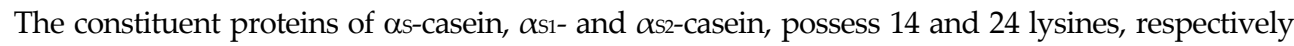
[2]. Lysine is an essential amino acid in humans and one in which many plant sources are lacking, therefore casein extracts form an effective nutritional supplement for cereals [2].

In addition to the variability inherent in their amino acid sequences, each of the caseins exhibit significant variability as a result of their degree of post-translational modification, 
disulfide bonding, genetic polymorphism and the manner in which they are hydrolysed by the milk protease, plasmin. In terms of the extent of phosphorylation, each of the four caseins may have various numbers of phosphate groups attached via their serine or threonine residues [4]. For example, as1-casein may have 8 or 9 , $\alpha$ s2-casein 10, 11, 12 or 13, $\beta$ casein may have 4 or 5 and $\kappa$-casein, 1, 2 or 3 [5]. It is not known whether this variability results from the action of casein kinases phosphorylating to different degrees or by phosphatases dephosphorylating to a greater or lesser extent [5]. The predominant caseins, $\alpha{ }^{2}-$ and $\beta$-casein, contain no disulfide bonds; however $\alpha$ s2- and $\kappa$-casein contain two cysteine residues which form intra- or intermolecular disulfide bonds under normal

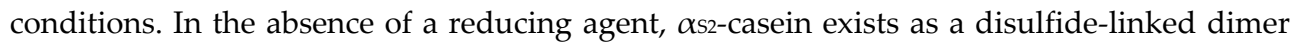
and $\kappa$-casein can adopt dimeric to decameric forms, depending on the pattern of intermolecular disulfide bonding. $\kappa$-Casein is also the only casein which is glycosylated and the degree of glycosylation varies so that ten different molecular forms of $\kappa$-casein are possible on this basis alone [4].

Genetic polymorphism is yet another source of variability in the caseins. This phenomenon was first described in 1955 in relation to $\beta$-lactoglobulin [6] and exists when the same protein exists in a number of forms, differing from one another in just a few amino acids. This has since been shown to occur in all dairy proteins. The milk of one animal may contain one polymorphic form alone, or both, and the occurrence of particular polymorphs is breedspecific $[7,8]$. Genetic variants are indicated by a latin letter i.e. $\alpha$ s1-casein has been shown to be present in bovine milk as $\alpha$ s1-caseinA - D; $\alpha$ s2- casein A - D; $\beta$-casein $\mathrm{A}^{1}, \mathrm{~A}^{2}, \mathrm{~A}^{3}-\mathrm{E}$ and $\kappa$-casein $A$ and $B$ [9]. With the combined variability between the caseins themselves, contributed by low sequence homology, glycosylation and disulfide bonding and within individual caseins due to the degree of phosphorylation and genetic polymorphism, this is a very interesting family of proteins. As will be described in greater detail in this chapter, the caseins have created even greater intrigue with the recent discovery of their chaperone abilities.

Structurally, the caseins are classified as 'intrinsically or natively disordered' proteins under physiological conditions [10,11]. This disordered structure, which is present to some extent even in globular proteins, is different to random coil conformation. In natively disordered proteins, conformations of these regions are still relatively fixed with respect to the $\phi$ and $\psi$ angles of the peptide bonds, as opposed to true 'random coil' polypeptide chains, which exhibit greater and more rapid fluctuation in bond angles [4]. The lack of well-defined structure in the casein proteins is believed to facilitate proteolysis and therefore ready absorption of amino acids and small peptides in the gut [2], but is another likely factor in the unwillingness of the caseins to crystallise to provide a 3D crystal structure [12]. Physical characterisations of caseins in solution and predicted 3D models have shown that the caseins have relatively little tertiary structure, but possess some secondary structure, similar to the classic 'molten globule' states described in [13]. The greatest degree of secondary structure exists in $\alpha$ s2- and $\kappa$-casein, mainly in the form of $\beta$-sheets and $\beta$-turns rather than $\alpha$-helix [14-16]. The formation of higher proportions of secondary and tertiary structural 
elements in the caseins is likely to be inhibited by high numbers of proline residues which distort protein folding into $\alpha$-helices and $\beta$-sheets [2].

Each of the casein proteins has a high degree of hydrophobicity as a result of containing approximately 35-45\% non-polar amino acids (e.g. Val, Leu, Phe, Tyr, Pro), but this does not preclude them from being quite soluble in aqueous solvents due to the presence of high numbers of phosphate and sulfur-containing amino acids, and in the case of $\kappa$-caseins, carbohydrates [2]. These hydrophobic regions are likely exposed in the caseins as a result of their flexible and relatively unfolded structure. The hydrophobicity tends to occur in patches along the sequence of the caseins, however, and is interspersed with hydrophilic regions. It is this feature that is credited with making the caseins good emulsifying agents a property exploited in the food industry. The clustered exposed hydrophobicity is also thought to be a major feature of the molecular chaperone action of the caseins [17] as discussed later in this chapter.

\subsection{Self-association, fibril formation and micellar arrangement of the caseins}

Although relatively small in size with molecular masses of 23.6 and $25.2 \mathrm{kDa}$ for $\alpha \mathrm{si}-$ and $\alpha$ s2-casein, respectively, $\alpha$-caseins readily associate with one another and with the other caseins ( $\beta$ - and $\kappa$-casein) to form large aggregates up to 1.4 MDa in size [18]. This tendency to form multimeric assemblies is likely to be another reason why it has not been possible to obtain crystal structures for the caseins thus far. In the presence of calcium, associations between the various caseins can lead to the formation of micelles [2]. These micelles are composed of approx. $94 \%$ protein and approx. $6 \%$ low molecular weight species such as calcium, phosphate, citrate and magnesium which together form 'colloidal calcium phosphate' [2] or amorphous calcium phosphate; APC [19]. Evolutionarily, it is thought that the formation of micelles has served as a means by which to increase the calcium concentration in milk over many millennia to satisfy its nutritional function without compromising physical stability [19]. The makeup of the micelle, which is roughly spherical in shape and has a radius of approx. $600 \mathrm{~nm}$ or less, comprises the amorphous calcium phosphate, more recently referred to as 'nanoclusters', bound to specific phosphorylated sequences in the surrounding $\alpha_{s 1}{ }^{-}, \alpha_{s 2}-$ and $\beta$-casein chains [19]. The major protein constituent of casein micelles, accounting for $65 \%$ of protein is $\alpha$ s-casein [4]. The function of $\kappa$-casein, present at the surface of the micelle, appears to be related to limiting the size of the micelle [19].

The C-terminal region of $\kappa$-casein is strongly hydrophilic, whereas the $\mathrm{N}$-terminal region is strongly hydrophobic [4]. Such amphipathic qualities have been shown to be of great importance for molecules residing at the interface between hydrophobic and hydrophilic environments in various biological contexts (e.g. the phospholipid cell membrane, the assembly of lipoprotein particles) and are no doubt also important in the stabilisation of the micelle in the aqueous environment of milk. Further evidence for the localisation of $\kappa$-casein at the surface of the micelle forming a diffuse outer region [20] was provided by the discovery that in the formation of cheese, the more hydrophilic C-terminal portion is the one 
cleaved by the action of rennet [2]. Recent Cryo-TEM and TEM studies have shown that the small electron-dense regions consistent with calcium phosphate nanoclusters are evenly distributed throughout the micellar structure rather than being sequestered within the core of the micelle [21-24] and that these structures, linked together by chains of caseins, were continuous throughout the entire micelle [25]. The sequestration of calcium phosphate, which accounts for $7 \%$ of the solute mass of bovine casein micelles, within a phosphoprotein matrix in this way is critical to maintaining the stability of these potentially very insoluble minerals in milk which would otherwise precipitate, compromising lactation [19]. It is the light scattering caused by these large $\left(10^{3}\right.$ to $\left.3 \times 10^{6} \mathrm{kDa}\right)$ casein micelles in a colloidal dispersion that is thought to give milk its characteristic white colour $[2,25,26]$. The caseins are also very stable at high temperatures, a property thought to be associated with their high phosphate content [2] and lack of well-defined structure [11] which makes them resistant to denaturation by heat and chemical agents. Milk may be heated at $100^{\circ} \mathrm{C}$ at its native $\mathrm{pH}$ ( 6.7) for 24 hours without coagulating and will withstand $140^{\circ} \mathrm{C}$ temperatures for $20 \mathrm{~min}$. The current ultra high heat treatments applied to milk and milk products are made possible by the extreme thermostability of the caseins [2]. Our studies have shown that solutions of individual $\alpha_{s 1}$ - and $\alpha_{s 2}$-caseins are stable at $70^{\circ} \mathrm{C}$ for a period of at least 8 hours at a concentration of $5 \mathrm{mg} / \mathrm{mL}$ [18].

Interestingly, both of the disulfide bond-containing caseins, $\kappa$ - and $\alpha$ s2-casein, have been shown to form amyloid fibrils under physiological conditions [27-30]. It has been suggested that casein proteins may have a propensity to form amyloid fibrils because they possessed similar structural features to the amyloid forming proteins tau, $\alpha$-synuclein and amyloid $\beta$ [31]. The similarity lies in the tendency of all four casein proteins to adopt a flexible and relatively unfolded conformation but also their possession of significant amounts of poly-Lproline (PPII) helix structure which likely arose from the relatively uniform distribution of proline residues $[2,31]$. In contrast to $\alpha$-helix, PPII helix is more open, flexible and extended and the conversion of this to antiparallel $\beta$-sheets, the precursor to amyloid fibril, is a highly energetically-favourable one [32]. As suggested in [33], other factors in the formation of amyloid fibrils must also be important, as only two of the four caseins (namely $\kappa-$ and $\alpha s_{2}-$ casein) form fibrils under physiological conditions. Whole casein does not form fibrils under the same conditions as $\kappa$ - and $\alpha_{\mathrm{s} 2}$-casein and this is thought to be related to the inhibitory action of other caseins present. It has been shown previously that both $\alpha$ s1- and $\beta$-casein are able to inhibit fibril formation by $\kappa$-casein [28].

\subsection{Separation and purification of $\alpha_{s 1}$ - and $\alpha_{s 2}-$ casein}

Caseins can be separated from whey proteins in milk by a variety of methods that are effective for large scale applications such as the acid precipitation already described [2]. The individual casein proteins can also be separated from one another by classical methods based on solubility differences and more recently via gel chromatography (summarised in [4]). In order to study as1and $\alpha$ s2-caseins separately, these proteins were purified from their associated form, $\alpha$ s-casein, by successfully employing the method previously described in reference [34] using a Q-Sepharose column with some minor modifications [17]. Subsequent investigation of the chaperone activities 
of individual $\alpha_{S 1}$ - and $\alpha_{s 2}$-casein proteins was then possible. As shown in Figure 1, purification gave an initial smaller peak corresponding to the predominant form of $\alpha_{2} 2$-casein, ass A-casein $11 \mathrm{P}$ (25.2 $\mathrm{kDa}$ with 11 phosphate groups attached), and a second, much larger peak corresponding to the predominant form of as1-casein, $\alpha \mathrm{si}_{1} \mathrm{~B}$-casein $8 \mathrm{P}$ (23.6 kDa; 8 phosphate groups attached). It would be logical to expect that the areas under these peaks to be roughly representative of the 4:1 ratio of as1:as2-caseins present in bovine milk, however, due to their differing amino acid compositions $\alpha s_{1}-$ and $\alpha$ s2-casein have quite different specific absorbances of 10.1 and $14.0 \mathrm{~A} 1 \% 1 \mathrm{~cm}$, respectively [2]. The smallest peak visible in Figure 1 is representative of a small amount of dimeric as2-casein eluting first from the column. This species had an approximate mass of $50 \mathrm{kDa}$ due to the presence of intermolecular disulfide bonds between cysteine residues at positions 36 and 40 [17].

Successful separation and purification of the constituent as-casein proteins was confirmed by SDS-PAGE and ESI-MS, which gave a major peak at 23,619 kDa (Figure 2). This closely corresponded to the major variant of $\alpha$ s-casein, $\alpha_{s 1} B$-casein $8 \mathrm{P}$. Unfortunately it was not possible to obtain a similar spectrum for $\alpha_{s 2} \mathrm{~A}$-casein $11 \mathrm{P}$, most likely as a result of the greater hydrophobicity of this casein and its propensity for amyloid fibril formation [17].

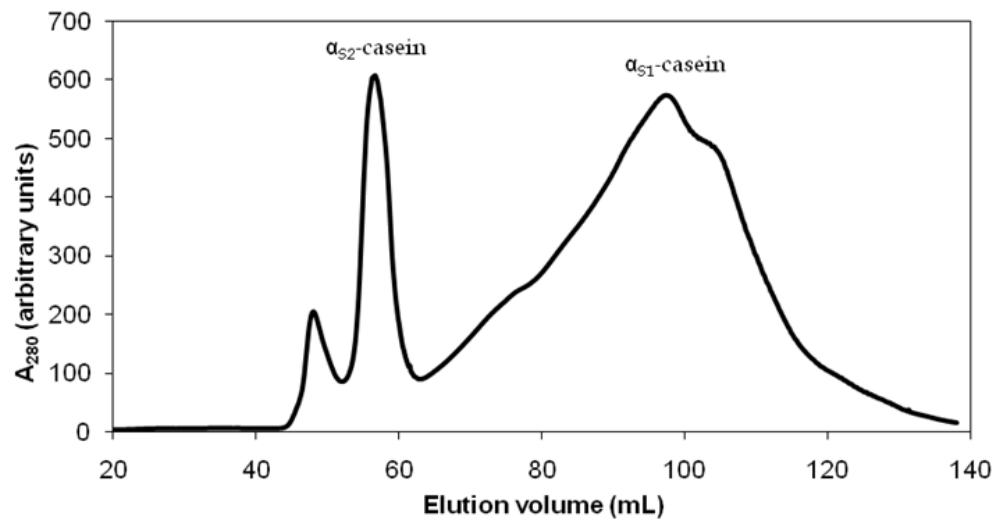

Figure 1. Purification of $\alpha s_{1}-$ and $\alpha$ s2-casein from total $\alpha s$-casein. Reprinted with permission from [17]. Copyright (2011) Elsevier Inc.

\subsection{Characterisation of purified $\alpha \mathrm{s} 1-^{-}$and $\alpha \mathrm{s}_{2}$-casein proteins}

Biophysical characterisation of the purified $\alpha_{s}$-casein proteins showed that the proteins possessed a similar degree of secondary structure to that expected from literature values [3, 35-38]. The far-UV CD spectra of purified $\alpha_{51}-, \alpha_{s 2}-$ and $\alpha$ s-casein proteins (Figure 3) show a minimum at approximately $202 \mathrm{~nm}$ for $\alpha s_{1}$-casein, $203 \mathrm{~nm}$ for $\alpha$ s-casein and $205 \mathrm{~nm}$ for $\alpha \mathrm{s}_{2}-$ casein and a second minimum for all three proteins at $222 \mathrm{~nm}$. Deconvolution of the far-UV CD data for $\alpha$ s1- $^{-}$and $\alpha$ s2-casein shown in Figure 3 was performed using SELCON software via the DICHROWEB database [39-43]. These data are summarised in Table 1. Deconvolution of data for as-casein could not be performed due to the presence of a 4:1 ratio of $\alpha$ s1: $\alpha s_{2}-$-casein, each with a different number of amino acid residues. 


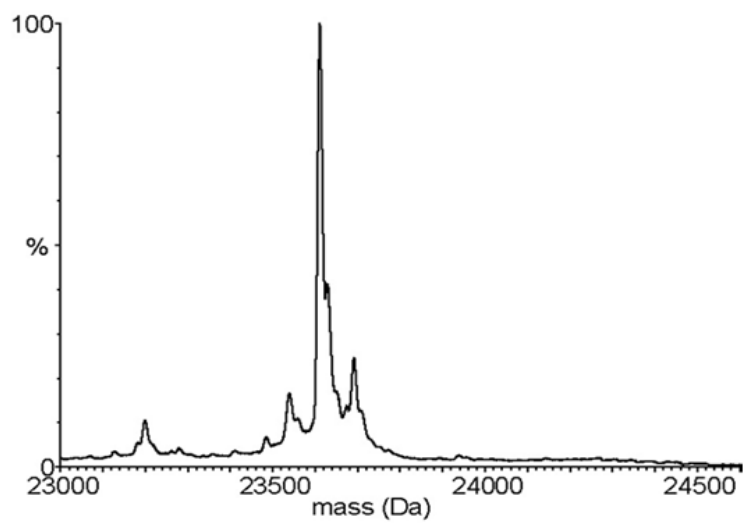

Figure 2. ESI-MS spectrum of purified $\alpha$ s1-casein with a major peak occurring at $23,619 \mathrm{kDa}$

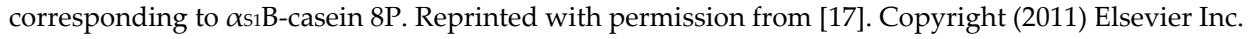

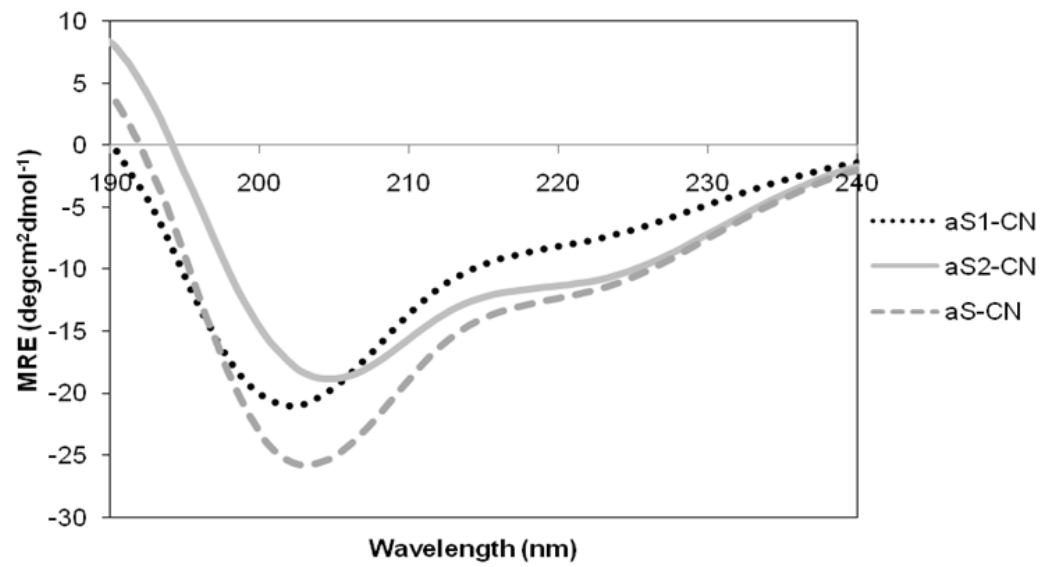

Figure 3. Far-UV CD spectrum of purified $\alpha_{s 1}-, \alpha_{22}-$ and $\alpha$ s-casein at $0.20-0.28 \mathrm{mg} / \mathrm{mL}$ in prefiltered 10 $\mathrm{mM}$ sodium phosphate buffer, pH 7.4. Reprinted with permission from [17]. Copyright (2011) Elsevier Inc.

\begin{tabular}{|c|c|c|c|c|}
\hline Protein & $\alpha$-helix (\%) & $\boldsymbol{\beta}$-sheet (\%) & $\boldsymbol{\beta}$-turns (\%) & Disordered structure (\%) \\
\hline as1-casein & 14 & 28 & 22 & 35 \\
\hline as2-casein & 18 & 26 & 22 & 33 \\
\hline
\end{tabular}

Table 1. Secondary structural elements of $\alpha s_{1}$ - and $\alpha s_{2}$-casein as determined by deconvolution of far-UV CD spectra [39-43].

\section{Introduction to molecular chaperones}

\subsection{The perils of protein folding}

Early experiments on the folding of ribonuclease in vitro revealed that all of the information required for a protein to fold into its native $3 \mathrm{D}$ conformation was contained within the 
primary sequence of that protein i.e. from the characteristics of amino acids and their positions in the polypeptide chain [44]. However, it also became evident that the folding of large, multi-domain proteins was complicated by incorrect intermolecular interactions involving the folding of the polypeptide chain [45] which prevented a proportion of proteins from reaching their native state, both in vitro [46, 47] and in vivo [48]. The process of protein folding, especially in the case of large proteins, appears to occur via a limited number of pathways. These pathways involve distinct intermediately-folded states known as 'molten globule' states [49]. This term is used to refer to a partially folded but compact state of a protein that has substantial amounts of secondary structure, but little or no tertiary structure [50]. In contrast to the natively folded state which is rigid and constrained, the molten globule state is not a single conformation but is instead a range of multiple conformations. These conformations are dynamic and rapidly interconvert with one another in response to the external environment [51] and they are also in equilibrium with more unfolded states [52]. Theoretical models have predicted a major loss of hydrophobic contacts in the molten globule compared to the natively folded state [50]. These intermediately folded states transiently expose previously buried hydrophobic areas on their surfaces and it is this characteristic that makes them prone to intermolecular association with other partially folded proteins, leading to aggregation and potential precipitation into insoluble aggregates $[53,54]$.

The currently accepted theory of protein folding is that natively folded proteins exist in equilibrium with less 'ordered' molten globule states. This 'folding/unfolding' pathway is reversible and slow, therefore it is possible for a protein that has partially unfolded but remains soluble to adopt a native state again provided it does not begin the process of aggregation. Once a molten globule state has begun to aggregate (either through interactions with other proteins or other molecules of the same protein), it has entered the fast and irreversible 'off-folding' pathway which ends with precipitation [55]. Within the cell, where proteins are present in high concentrations (e.g. $340 \mathrm{~g} / \mathrm{L}$ in E. coli) and rates of protein production can be extremely high, folding of nascent proteins is further challenged by molecular crowding. Under such conditions, there are a great number of opportunities for inappropriate protein interactions. As the three-dimensional structure of a protein largely determines its function, the incorrect folding of proteins has the consequence of loss of function. It is not surprising therefore that abnormalities in protein folding form the basis of many human pathologies such as prion diseases and amyloidoses [56, 57].

\subsection{The role of molecular chaperones}

Molecular chaperones are a diverse group of proteins that act to prevent 'improper' interactions between other proteins that may result in aggregation and precipitation [58]. They ensure high fidelity protein folding and assembly without becoming part of the natively folded structure. In doing so, chaperones perform important roles in the stabilisation of many other proteins both intra- and extracellularly. Proteins from many unrelated families have been identified as possessing molecular chaperone function [59]. There are four key features that must be exhibited by a protein in order for it to be classified 
as a molecular chaperone: 1) suppression of aggregation during protein folding, 2) suppression of aggregation during protein unfolding, 3) influence on the yield and kinetics of folding and 4) effects exerted at near stoichiometric levels [60]. Many molecular chaperones have been identified in the eukaryotic cell, particularly in the endoplasmic reticulum and cytosol where they ensure correct folding, transport and biological activity of countless proteins [61]. Some chaperones act in sequence with others, passing on intermediately folded proteins to continue the folding process [62, 63]. Other chaperones, such as the small heat-shock proteins which are explained in greater detail later in this chapter, specifically interact with proteins on the off-folding pathway only. These intermediates, more prone to aggregation, are the ones recognised by the chaperone and stabilised against precipitation [58, 64].

\subsection{Molecular chaperones are also heat-shock proteins}

The expression of molecular chaperones is markedly increased (10 to 20 fold) under conditions of physiological stress (e.g. heat, reduction, oxidation stresses) - a feature which explains their other moniker as 'heat-shock' proteins (Hsps). It has been demonstrated that both the protein coding sequences $[65,66]$ and regulatory sequences [67] of some heat-shock genes have been highly conserved $[68,69]$.

\subsection{The sHsps and clusterin}

There are several classes of heat shock proteins, and the accepted nomenclature is based on their approximate molecular mass on SDS-PAGE i.e. Hsp60 and Hsp70 are 60 and $70 \mathrm{kDa}$, respectively. A subset of the Hsps is called the small heat-shock proteins, or sHsps, with molecular masses of monomers ranging from 15-30 kDa. These chaperones act in an ATPindependent manner, which unlike Hsp60 and Hsp70 do not actively refold in the presence of ATP. Instead, they interact with partially unfolded or 'stressed' proteins, stabilising them in a soluble, high molecular weight complex to prevent their precipitation from solution [70]. They do not interact with natively folded proteins, nor with those that have already aggregated [71]. Rather than simply serving as a one-way 'sink' for denatured proteins, however, previous studies have shown that in addition to their ability to interact with and stabilise stressed proteins, some sHsps such as Hsp25 [58], $\alpha$-crystallin [72] and clusterin [73] act co-operatively with ATP-dependent chaperones (e.g. Hsp70) to refold the stressed protein when the stress is removed and normal cellular conditions are restored. Studies on $\alpha$-crystallin have shown that the presence of ATP causes the sHsp to undergo a conformational change whereby the stressed target protein is released facilitating refolding by chaperones such as Hsp70 [74]. Members of the sHsp family have several features in common, including size and amino acid sequence homology within the C-terminal domain [55]. There have been 10 human sHsps identified thus far, including $\alpha_{A}-$ and $\alpha_{B}$-crystallin (discussed below), Hsp27 and its murine equivalent, Hsp25 [75, 76].

The sHsps are also able to exist as monomeric and dimeric species which associate with one another to form large multimeric complexes, somewhat akin to the behaviour of the casein 
proteins both within and without the casein micelle. Our studies have shown that as-casein, and more specifically, as1- and as2-casein, also act as molecular chaperones and do so in a manner that is similar to the sHsps and an extracellular chaperone, clusterin. Clusterin is a secreted mammalian chaperone present in bodily fluids such as blood and semen. Like the sHsps, clusterin is highly conserved and is upregulated in many cell types under conditions of stress and in protein misfolding diseases such as Alzheimer's disease [77]. It is a disulfidelinked dimer which is $75-80 \mathrm{kDa}$ in size and highly glycosylated [73, 77]. Clusterin has been shown to aggregate in aqueous solution and at physiological $\mathrm{pH}$ values is present in monomeric, dimeric and multimeric states [78]. Like the sHsps, clusterin is an ATPindependent molecular chaperone capable of stabilising a wide array of target proteins [73, 77]. Stoichiometrically, clusterin has been shown to protect stressed target proteins at levels consistent with the concentration range of clusterin normally found in extracellular fluids (50 - $370 \mu \mathrm{g} / \mathrm{mL}$ in human serum and $2.1-15.0 \mathrm{mg} / \mathrm{mL}$ in human seminal fluid). In addition, clusterin displays greater chaperone activity with smaller target proteins versus larger ones [77] indicating that it has the ability to interact differently with various target proteins depending on the conditions. This variability of chaperone action has also been demonstrated extensively in studies on sHsps such as $\alpha$-crystallin which have been shown to exhibit increased or decreased chaperone activity depending on the mode of aggregation of a target protein [79-81].

$\alpha$-Crystallin is a member of the small heat-shock protein family and has for some time been known to play a major role in stabilising other crystallin proteins in the eye lens. It was identified some time ago that $\alpha$-crystallin performed an important structural role in the lens, as a member of the crystallin family of proteins which also comprises $\beta$ - and $\gamma$-crystallin [82]. In its normal state, the lens is transparent despite the high concentrations of these proteins in the cell cytoplasm (33\% in the human lens and 50\% in rat and bovine lenses [83]). Such a high concentration of proteins would ordinarily cause a significant degree of light scatter, but these highly homologous proteins adopt a critical short-range order that allows them to exist in a dense glass-like liquid resulting in unimpeded transmission of light through the lens $[84,85]$. Their structural integrity therefore is of prime importance and disruption to their three-dimensional arrangement as a result of chemical modification, for example, has been shown to result in increased light scattering manifesting as cataract [86]. Due to the lack of protein turnover in the lens over the lifetime of an organism, the occurrence of $\alpha$ crystallin in the lens allows it to perform a second, equally important role as a molecular chaperone. Numerous studies have shown that under conditions of cellular stress, $\alpha$ crystallin interacts with not only other crystallins but with a plethora of other proteins, stabilising them against precipitation. Its wide tissue distribution and localisation in various disease states associated with protein misfolding also provides strong evidence for the role of $\alpha$-crystallin as a molecular chaperone outside the lens. Like $\alpha$ s-casein, $\alpha$-crystallin is made

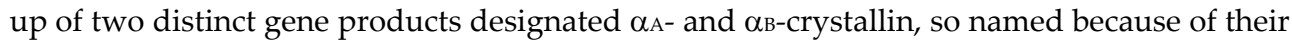
relatively acidic and basic properties. The individual subunits of $\alpha$-crystallin are present in a 3:1 ratio $\left(\alpha_{\mathrm{A}}: \alpha_{\mathrm{B}}\right)$ in the human lens, are each $\sim 20 \mathrm{kDa}$ in size and these proteins readily associate with one another to form dimeric and multimeric species. These multimers can be 
up to 1.2 MDa in size and exhibit dynamic subunit exchange. As such, $\alpha$-crystallin, like $\alpha$ scasein has been resistant to crystallisation and a precise picture of its mechanism of action is still to be elucidated. Almost 100 years after being identified in the lens, individual $\alpha_{A}-$ and $\alpha_{B}$-crystallin subunits were found in non-lenticular tissues [87-91]. These proteins and other sHsps have been identified in the brain where they are associated with neurodegenerative diseases such as Alzheimer's, Creutzfeldt-Jakob and Parkinson's diseases (summarised in [92]).

\subsection{Putative mode of action of sHsps and clusterin}

As reviewed in [93], current theories of the chaperone action of both sHsps and clusterin centre around their ability to expose hydrophobic regions that interact with partially folded target proteins, also known as 'disordered' molten globules, forming soluble, high molecular weight complexes and preventing them from precipitation. It has been shown that sHsps do not interact with target proteins that are natively folded, completely denatured, or those in stable molten globule states [55, 94-97]. The stoichiometry of sHsp and clusterin interaction with target proteins suggests that one oligomer of chaperone can bind to and stabilise many molecules of stressed target protein, in fact, CryoEM and X-ray solution studies on stressed $\alpha$-lactalbumin and $\alpha_{\mathrm{B}}$-crystallin showed that the target protein coated the exterior surface of the $\alpha \mathrm{B}$-crystallin oligomer upon formation of the chaperone-target protein complex [98, 99].

The relatively hydrophobic nature of the more globular portion of the sHsp is balanced by the adjoining flexible, dynamic C-terminal extension which is solvent exposed and hydrophilic and is thought to play a major role in ensuring the solubility of the huge complex formed upon chaperone interaction [100, 101]. It has also been demonstrated that the C-terminal extension in $\alpha$-crystallin is critical for oligomeric assembly [79]. Altered 'spacing' of chaperone molecules resulting from modification of the C-terminal sequence results in abnormally sized oligomers with perturbed structure, physical stability and chaperone function [79]. The large, oligomeric forms of sHsps are thought to exist in dynamic equilibrium with smaller species which rapidly interchange with the oligomer $[102,103]$. This equilibrium of subunit exchange is believed to be key to sHsps broad target protein specificity [97, 103-105], and although clusterin shares many features with the sHsps in terms of its chaperone action, the potential importance of subunit exchange for it has not been described to date [106].

\section{3. $\alpha$ s-Casein as a molecular chaperone}

The casein proteins and their derivatives have been used by the food industry as important nutritional and stabilising proteins for many years [4]. Early studies showed that whole casein (i.e. $\alpha s^{-}, \beta$ - and $\kappa$-casein) prevented heat induced aggregation of whey proteins, even in calcium-containing systems [107, 108]. This stabilising action of the caseins on heatdenatured target proteins was proposed to occur through non-specific interactions and opened up a new avenue of uses for casein proteins in stabilising both milk and non-milk proteins and thereby contributing to novel properties of milk products. It was then 
demonstrated in 1999 that individual as-casein possessed molecular chaperone activity [109]. Since then, $\beta$ - and $\kappa$-casein have both been shown to also act as molecular chaperones $[18,33,110-112]$. The presence of high numbers of phosphate groups in the casein proteins appears to be important for chaperone action against amorphously aggregating target proteins under both reduction and heat stress, with studies showing that removal of these in $\alpha s-$ and $\beta$-casein reduced their ability to prevent the aggregation of target proteins $[113,114]$. Previous work on $\alpha$ s-casein showed that it prevented the stress-induced aggregation of natural target proteins such as the whey proteins $\beta$-lactoglobulin and bovine serum albumin, but also of unrelated proteins such as alcohol dehydrogenase and carbonic anhydrase [109]. In acting as a molecular chaperone under these conditions, as-casein was able to interact with partially unfolded target proteins and prevent their incorporation into insoluble aggregates which would then have formed precipitates. Furthermore, when added to partially aggregated reduction-stressed insulin, as-casein not only prevented further aggregation of insulin but facilitated its re-solubilisation when present at a 2:1 (w:w) ratio [109].

As shown in Figure 4, the putative mode of action of as-casein is based on a similar model proposed for sHsps [70] where a natively folded protein (N) unfolds via a number of intermediately folded states ( $\mathrm{I}_{1}, \mathrm{I}_{2}$ etc.) or 'molten globule' states on its way to the unfolded state $(\mathrm{U})$. This folding and unfolding is fast and reversible and involves the exposure of hydrophobic regions normally buried in the interior of the protein.

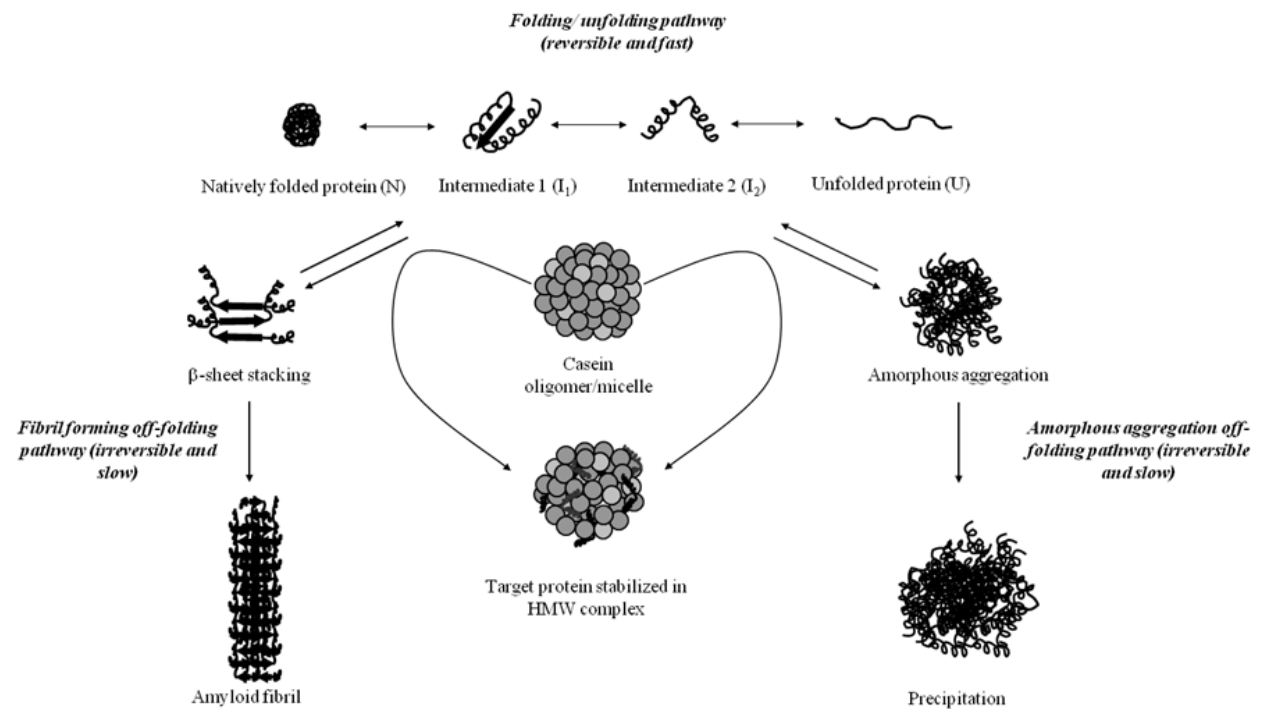

Figure 4. Putative mechanism of action of $\alpha$-casein showing its interaction with target proteins on the folding and off-folding pathways. See text for explanation. Reprinted with permission from [33]. Copyright (2009) Dairy Industry Association of Australia.

Under conditions of cellular stress, when intermediately folded states are present for longer periods, self-association is promoted by the prolonged exposure of hydrophobic 
surfaces. When self-association occurs, the intermediately folded states enter the offfolding pathways which are slow and irreversible and may lead to either amorphous aggregation as shown on the right hand side of the figure or to fibril formation as shown on the left. Amorphous aggregates result from disordered aggregation and lead to the formation of insoluble protein precipitates. Conversely, the ordered amyloid pathway leads to highly ordered $\beta$-sheet stacking giving cross $\beta$-sheet fibrils. Casein micelles or oligomeric forms of $\alpha$ s- or $\beta$-casein are able to interact with partially folded proteins and stabilise them against aggregation and precipitation by forming a soluble high molecular weight (HMW) complex [33].

\subsection{Assessment of molecular chaperone activity}

Assessment of molecular chaperone activity traditionally involves an in vitro assay in which a target protein is subjected to a form of stress similar to what would be encountered under physiological conditions (e.g. heat, oxidation, reduction etc.) in the presence and absence of different amounts of chaperone. These assays are not complicated by the aggregation of the chaperone itself which is stable under these conditions, and suppression of aggregation has been shown to be specific to the action of molecular chaperones as substitution of these with non-chaperones (e.g. ovalbumin) has been shown to have no effect on the extent of target protein precipitation [73]. For the assessment of amorphous aggregation, light scattering of the proteins in solution at $360 \mathrm{~nm}$ is monitored over time, whereas for fibril forming proteins, amyloid formation is monitored by increasing Thioflavin T (ThT) fluorescence. These values increase to a maximum over the timeframe of the experiment and are used to estimate $\%$ protection provided by the chaperone as per the following formula:

$$
\% \text { Protection }=\frac{100 *\left(\Delta \mathrm{I}-\Delta \mathrm{I}_{\text {chaperone }}\right)}{\Delta \mathrm{I}}
$$

(1) Calculation of percentage protection of a target protein by molecular chaperone. In this

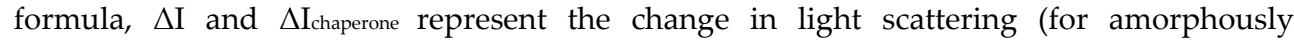
aggregating target proteins) or in Thioflavin T (ThT) fluorescence (for amyloid forming target proteins) in the absence and presence of the chaperone, respectively [79].

\section{2. $\alpha$ s-Casein stabilises proteins via formation of soluble high molecular weight complexes}

Consistent with the well-characterised properties of a molecular chaperone, it has been shown that $\alpha$ s-casein (and $\beta$-casein) form soluble, high molecular weight (HMW) complexes with stressed target proteins that can be identified by size-exclusion chromatography. These complexes, formed between $\alpha$ s-casein and heat-stressed $\beta$-lactoglobulin or apo- $\alpha$ lactalbumin eluted from the column at a retention time correlating to an approximate mass of 1.8 MDa [18]. Control experiments showed that in the absence of a chaperone, heat stressed $\beta$-lactoglobulin also formed large, multimeric species but these were largely insoluble [18]. Mixtures of the individual whey proteins and $\alpha$ s-casein that were not exposed 
to heat stress eluted as separate peaks with elution times corresponding to the individual proteins i.e. there was an absence of a target protein-chaperone or HMW complex. Additional experiments showed that the elution time of $\alpha$ s-casein was not altered in any discernible way by the addition of heat stress [18].

The molten globule states of a natural target protein of $\alpha$-casein, $\alpha$-lactalbumin, have been well characterised [13, 55, 115-122]. Intermediately folded states of the apo- form of $\alpha$ lactalbumin provide an ideal model for the investigation of protein folding and unfolding and therefore the action of molecular chaperones when present in solution. The molten globule states of apo- $\alpha$-lactalbumin exhibit a relatively compact structure in which a secondary structure is largely preserved, but tertiary structure is lost [123]. A characteristic of these states is that they expose significant amounts of hydrophobicity to solution as a result of their being 'uncovered' from the interior of the previously natively folded protein and it is these exposed hydrophobic areas that appear key to their interaction with molecular chaperones [124, 125]. Destabilisation of $\alpha$-lactalbumin upon removal of its calcium ion by a chelating agent such as EDTA induces a conformational change that further exposes the disulfide bonds of the protein to reduction with DTT [122]. Under this reduction stress, $\alpha$-lactalbumin adopts a molten globule state that is structurally unstable and similar to that formed at $\mathrm{pH} 2.0$ [13]. This state, in the absence of a molecular chaperone, such partially unfolded proteins will readily aggregate and precipitate. When monitored via realtime ${ }^{1} \mathrm{H}$ NMR spectroscopy, the formation of the molten globule state, its aggregation and eventual precipitation can be visualised. The aromatic protons in the region of the spectrum from 6-8 ppm can be attributed almost exclusively to the signals of protons in the target protein, which is small $(14.4 \mathrm{kDa})$ and monomeric. Resonances arising from aromatic protons in as-casein are relatively broad by comparison, so that even in the presence of added chaperone, the structural alterations in the target protein are easily observed. Isolated resonances arising from tyrosine 3,5 ring protons at $6.8 \mathrm{ppm}$ are therefore a reliable indicator of molten globule formation and stabilisation in $\alpha$-lactalbumin $[18,122,126]$. The well-resolved resonances visible at Time 0 are representative of the native state and are quickly lost with the addition of DTT. In the absence of as-casein (Figure 5A), an initial increase in resonance arising from the Tyr $(3,5)$ protons can be observed from $\sim 0-200 \mathrm{~s}$ following the addition of DTT. This period represents the reduction of the disulfide bonds in $\alpha$-lactalbumin by DTT, giving the molten globule state which in the absence of chaperone is prone to aggregation then precipitation [122] after a period of approximately $1000 \mathrm{~s}$ [18]. In the presence of a 2:1 (w:w) ratio of $\alpha$ s-casein to apo- $\alpha$-lactalbumin (Figure $5 \mathrm{~B}$ ), signals arising from the aromatic protons are preserved, indicating that the molten globule state of $\alpha$-lactalbumin is stabilised by the interaction between the two proteins. As shown in Figure $5 \mathrm{C}$, in the absence of $\alpha$-casein the rate of decay of the Tyr $(3,5)$ resonance of apo- $\alpha$ lactalbumin is rapid, occurring at rate of $2.70( \pm 0.11) \times 10^{-3} \mathrm{~s}^{-1}$ whereas in the presence of $\alpha \mathrm{s}^{-}$ casein it is approximately $50 \%$ slower at $1.25( \pm 0.08) \times 10^{-3} \mathrm{~s}^{-1}[18]$.

Extrinsic fluorescence studies have shown that upon formation of a high-molecular weight complex between $\alpha$ S-casein and reduction stressed insulin, a conformational change in one or both proteins resulted in an increase in clustered, exposed hydrophobicity. The other 
casein proteins, $\beta$ - and $\kappa$-casein also exhibited similar increases in hydrophobicity in the presence of reduction stressed insulin, implying that similar interactions were occurring during formation of the chaperone-target protein complex [18]. A mixture of the three caseins ( $\alpha s^{-}, \beta$ - and $\kappa$-casein) combined according to their approximate proportions in bovine milk ( $60 \%, 25 \%$ and $15 \%$, respectively), exhibited considerably increased exposure of clustered hydrophobic areas, indicating a synergy between the various subunits during stabilisation of stressed insulin [18]. Intrinsic (tryptophan) fluorescence studies showed that the tryptophan residues in the C-terminal region of $\alpha$ s-casein were exposed to a more nonpolar environment as a result of the interaction with the reduced insulin B-chain, and may indicate involvement of this region of the chaperone with the hydrophobic (bound) target protein [18].
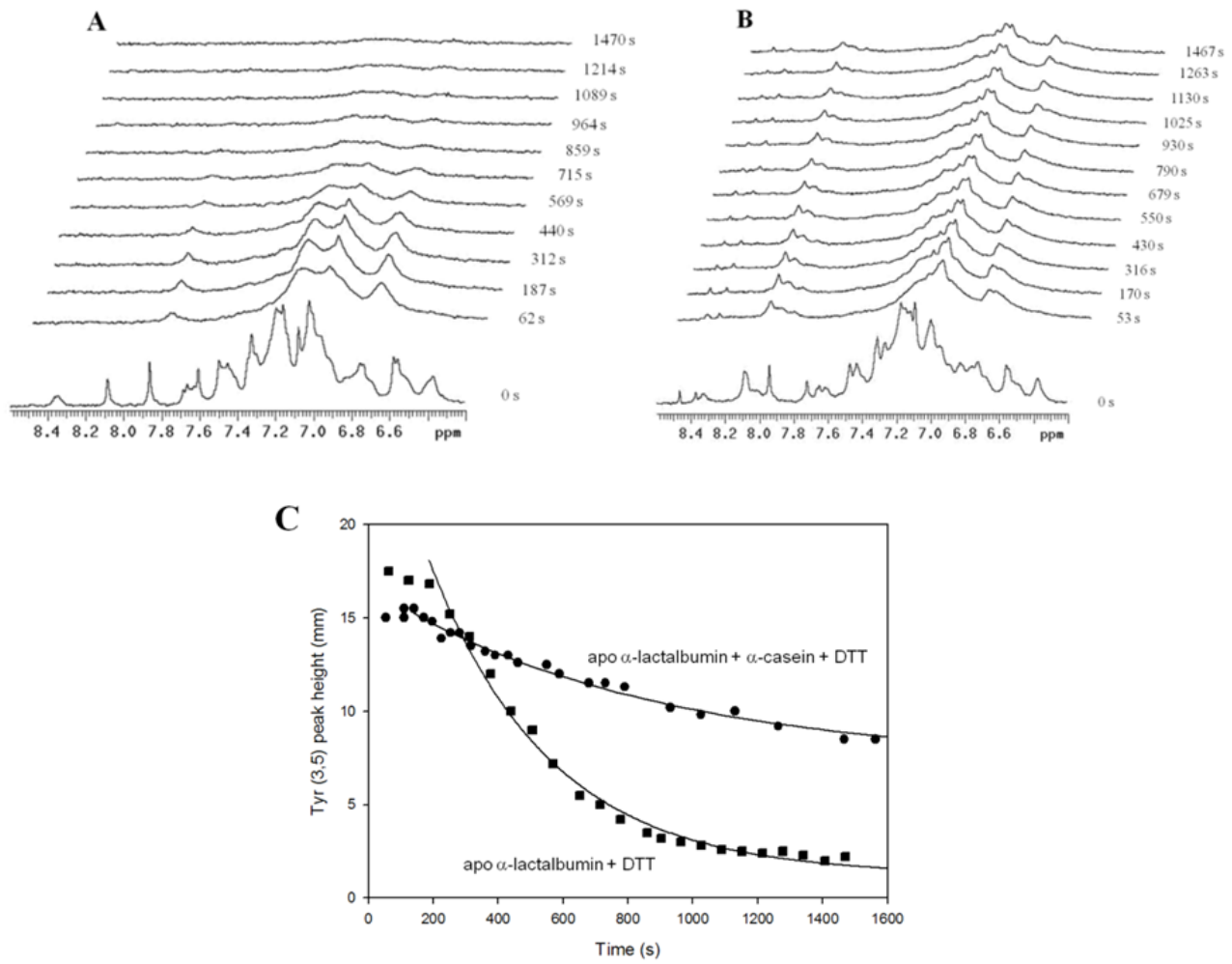

Figure 5. Real-time ${ }^{1} \mathrm{H}$ NMR spectroscopy of apo- $\alpha$-lactalbumin under reduction stress at $37^{\circ} \mathrm{C}$ in the presence and absence of $\alpha$ s-casein. Stacked plots of $1 \mathrm{D}^{1} \mathrm{H}$ NMR spectra show molten globule formation by reduced apo- $\alpha$-lactalbumin in A) the absence and B) the presence of $\alpha$ s-casein at a 2:1 (w:w) ratio. First-order decay of the resonance arising from the tyrosine $(3,5)$ ring protons at 3.5 ppm in both cases (C) was used to calculate rates i.e. peak height $(\mathrm{mm}) \mathrm{v}$ time (s). Reprinted with permission from [18]. Copyright (2005) American Chemical Society. 


\subsection{Effects of temperature, $\mathrm{pH}$ and molecular crowding}

As shown in [18], as-casein displayed temperature dependence in preventing aggregation of the reduced insulin B-chain, with comparatively better chaperone ability observed at $25^{\circ} \mathrm{C}$ compared to that at $37^{\circ} \mathrm{C}$. This was in keeping with previous studies that showed that $\alpha$ scasein was a considerably better chaperone at lower temperatures, giving $52 \%$ protection of insulin aggregation at $27^{\circ} \mathrm{C}$ compared to almost complete protection at $18^{\circ} \mathrm{C}$ [109]. This 'cold shock protein' characteristic is quite different to the temperature effects of other molecular chaperones such as $\alpha$-crystallin and tubulin, which display enhanced chaperone activity at increased temperatures [127-129]. At temperatures above $30^{\circ} \mathrm{C}, \alpha$-crystallin undergoes structural transitions that involve rearranging and/or increasing hydrophobic surfaces, enhancing hydrophobic interactions between the chaperone and the target protein [124, 125]. Conversely, clusterin's chaperone ability appears to be quite independent of temperature effects [130]. The properties of $\alpha$ s-casein that allow it to chaperone at lower temperatures are reflected in the fact that greater amounts of $\alpha$ s-casein have been identified in mammals inhabiting low temperature zones compared to those in more temperate climates [131, 132] which may indicate an important stabilising role in physiological adaptation to low temperatures. Both $\beta$ - and $\kappa$-casein also display chaperone activity, but in contrast to $\alpha$ s-casein, the chaperone action of these proteins does not appear to be as dependent on temperature as $\alpha$ s-casein [18]. In stabilising insulin, apo- and holo- $\alpha-$ lactalbumin as target proteins, $\beta$ - and $\kappa$-casein did not provide as much protection against precipitation as $\alpha$ s-casein on a w:w and molar basis, but were similar to each other in their efficacy [18]. This was in contrast to previous reports which described greater chaperone action in $\beta$-casein compared to $\alpha$ s-casein in stabilising heat stressed catalase and reduction stressed lysozyme [110], whereas others found that $\alpha$-casein was better than $\beta$-casein at preventing the aggregation of heat-stressed ovotransferrin [113]. This apparent disparity in the relative chaperone performances of the casein proteins is likely to be related to their broad target protein specificities. The same observations have been made in relation to the chaperone action of sHsps and chaperone efficiency has been shown to be dependent upon the size of the target protein and the rate and mode of aggregation, as previously discussed [79-81]. A combined form of the casein proteins (60\% $\alpha \mathrm{s}^{-}, 25 \% \beta$ - and $15 \%$-casein) was shown to possess similar chaperone activity to that of $\alpha$ s-casein alone [18].

In the investigation into the mechanism of chaperone action of $\alpha$ s-casein, experiments with its natural target protein, $\beta$-lactoglobulin, have been performed under heat stress at $70^{\circ} \mathrm{C}$ $[18,109]$. Obviously this level of heat stress is not physiologically appropriate, but the ability of as-casein to stabilise other dairy proteins under extreme heat stress is of importance to the dairy industry which employs treatment processes such as pasteurisation and ultra-high temperature treatment [18]. In these studies, it was found that $\mathrm{pH}$ had a major effect on the chaperone's ability to suppress the aggregation of the target protein. The ability of as-casein to suppress the aggregation of $\beta$-lactoglobulin at a $0.25: 1(\mathrm{w}: \mathrm{w})$ ratio decreased from $73 \%$ at $\mathrm{pH} 7.0$ to $33 \%$ at $\mathrm{pH} 7.5$ and $19 \%$ at $\mathrm{pH} 8.0$ after $450 \mathrm{~min}$ [18]. This is likely to be related to the rate at which $\beta$-lactoglobulin aggregates at higher $\mathrm{pH}$ values and may also be related to changes in the chaperone ability of $\alpha$ s-casein at more alkaline $\mathrm{pH}$ values. At slightly alkaline 
$\mathrm{pH}$ values, the histidine residues of $\alpha$ s-casein deprotonate ( $\alpha$ si-casein has five histidines and as2-casein, three) and it is feasible that this results in a loss of electrostatic contacts between the subunits, disrupting their ability to effectively bind the target protein [18].

A pH dependence is also exhibited by clusterin, which is in fact a better chaperone at more acidic $\mathrm{pH}$ values [130]. This is believed to be due to the increased dissociation of clusterin from its larger multimeric state at acidic $\mathrm{pH}$ values [130]. Conversely, $\alpha$-crystallin is less effective as a chaperone at slightly acidic $\mathrm{pH}$ values [130,133] but this is thought to be due to subtle structural changes in the protein with a change in $\mathrm{pH}$ rather than a change in aggregation state [134]. It may also be that at increased $\mathrm{pH}$ values $\alpha$ s-casein is less effective as a chaperone against $\beta$-lactoglobulin aggregation because the nature of the aggregation changes at more alkaline $\mathrm{pH}$ values. Greater intermolecular disulfide bond formation produces oligomers of $\beta$-lactoglobulin which then polymerise to form an aggregate. It is likely that $\alpha$ s-casein is similar to $\alpha$-crystallin in that it cannot interact with and stabilise these forms of aggregated proteins as effectively as those that aggregate in a nucleationdependent manner [135]. Other factors that have been shown to influence the nature and rate of target protein aggregation also have an impact on as-casein's chaperone action. One of these is molecular crowding. Experiments were conducted in the presence of $10 \%$ dextran in order to simulate the protein-rich environment of milk and a greater rate of target protein (insulin, apo- and holo- $\alpha$-lactalbumin) precipitation was observed under these conditions [18]. This increased rate of aggregation affects $\alpha$ s-casein's chaperone ability in the same way as described previously for $\alpha$-crystallin, other sHsps and clusterin, which are all poorer chaperones with rapidly aggregating target proteins [94, 96, 122, 136, 137].

\section{4. $\alpha$ s-Casein is unable to protect enzymes from loss of function due to heat stress}

As previously discussed, it is known that molecular chaperones such as sHsps interact with and bind partially unfolded target proteins in molten globule-like states, but not once they have begun to aggregate [71]. The chaperone behaviour of $\alpha$ s- and $\beta$-casein appears different in this regard, with both having been shown to re-solubilise aggregated DTT-treated insulin $[109,110]$. According to reference [138], one of the features of a protein used to classify it as a molecular chaperone is that it be able to aid in the recovery of lost biological activity. Like the sHsps and clusterin, however, as-casein is unable to prevent the loss of activity in enzymes induced by heat stress. Our experiments with catalase, GST and ADH show that the presence of as-casein at a 1:1 (w:w) ratio does not protect these enzymes to any significant extent against heat-induced loss of function (Figure 6).

\section{5. $\alpha$ s-Casein is ATP-independent in its chaperone action}

In order to obtain further insight into the molecular mechanism of action of as-casein, the effect of ATP on its chaperone function was also investigated [17; Treweek, Price \& Carver, unpublished work]. Previous studies have shown that $\alpha$ s-casein acts in a similar manner to small heat shock proteins (sHsps) and clusterin [17, 18, 28, 29, 33]. A major characteristic of 

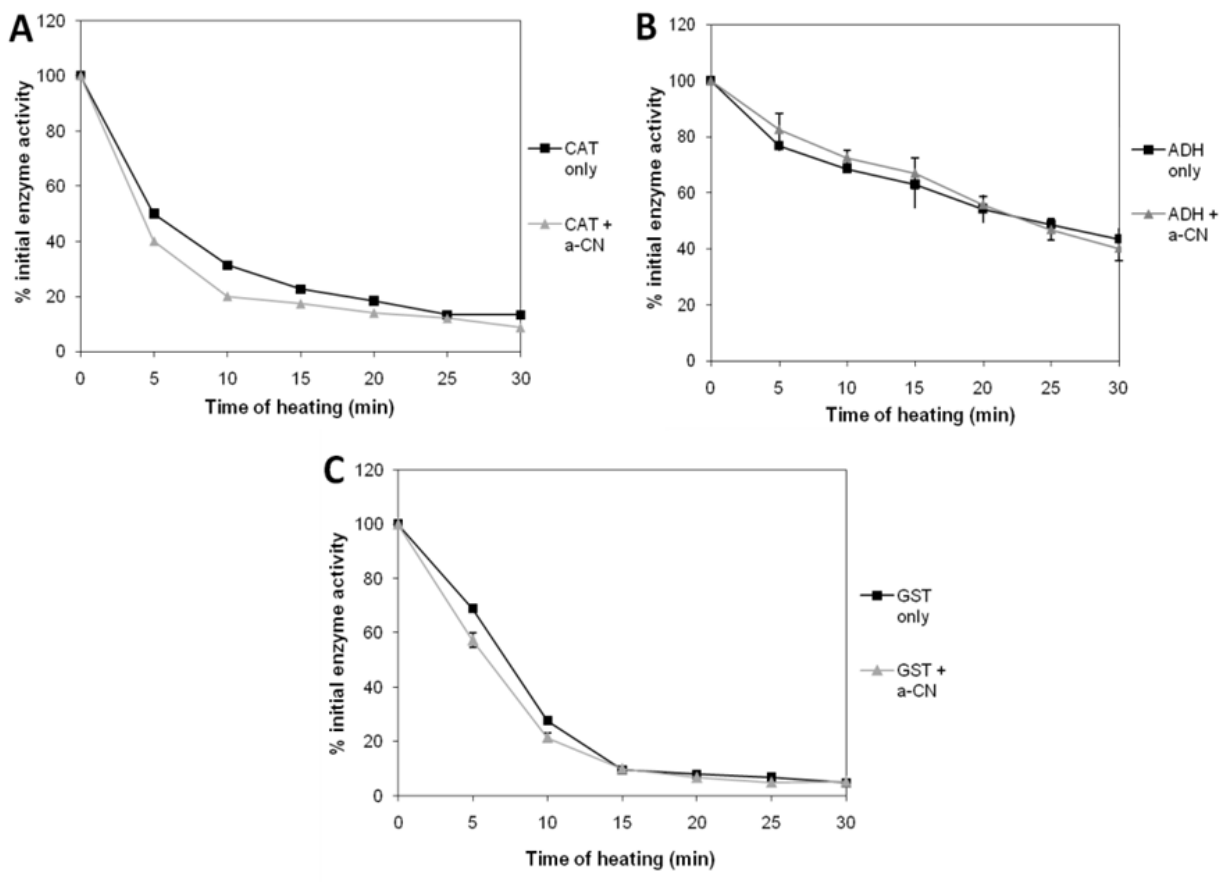

Figure 6. Loss of enzyme activity (catalase, CAT; ADH, alcohol dehydrogenase; GST, glutathione-Stransferase) with heat stress at $55^{\circ} \mathrm{C}$ and the effect of addition of as-casein at a 1:1 (w:w) ratio. Values represented are means of independent triplicate measurements and error bars shown are standard deviations of the mean which in some cases are too small to be visible. Reprinted with permission from [17]. Copyright (2011) Elsevier Inc.

sHsps and clusterin is that they function in an ATP-independent manner consistent with their inability to refold stressed proteins [139-141]. ATP levels in milk are relatively low (5 $\mu \mathrm{M})$ and as such it is likely to be non-essential to $\alpha$ s-casein's chaperone activity, however, it is an important mechanistic tool. A similar study on clusterin (which is also extracellular and as such experiences low physiological ATP levels) provided valuable insight into the ATP-independent action of the chaperone in binding the stressed enzymes catalase, $\mathrm{ADH}$ and GST [73]. Subsequent refolding of bound target proteins to clusterin and sHsps (e.g. Hsp25 and $\alpha$-crystallin) is achieved via ATP-dependent chaperones such as Hsp70 $[58,72]$. The presence of physiologically relevant levels of ATP on the ability of as-casein to suppress aggregation of stressed target proteins (specifically catalase, ADH and insulin) was investigated and it was found that the chaperone action of as-casein was unaffected by the presence of ATP [17; Treweek, Price \& Carver, unpublished work]. In addition, the ATPase activity of as-casein was assessed and it was found that as-casein had no detectable ATPase activity either on its own or during chaperone action i.e. when interacting with heat stressed $\beta$-lactoglobulin in a chaperone complex (Figure 7) [Treweek, Price \& Carver, unpublished work]. 


\section{6. $\alpha$ s-Casein does not bind target proteins in a way that allows refolding by Hsp70}

As previously mentioned, some sHsps such as Hsp25 [58], $\alpha$-crystallin [72] and clusterin [73] act co-operatively with ATP-dependent chaperones such as Hsp70 to refold stressed proteins when the stress is removed and cellular conditions are restored [139]. Studies on $\alpha-$ crystallin have revealed that a region in the conserved $\alpha$-crystallin domain of $\alpha \mathrm{B}$-crystallin undergoes structural modification upon binding of ATP [142] and that this conformational change causes $\alpha$-crystallin to release stressed target proteins, facilitating their refolding by chaperones such as Hsp70 [74]. Although not a natural component of milk, Hsp70 was used to probe the mechanism of as-casein's chaperone action and to allow comparisons with better characterised chaperones to be made.

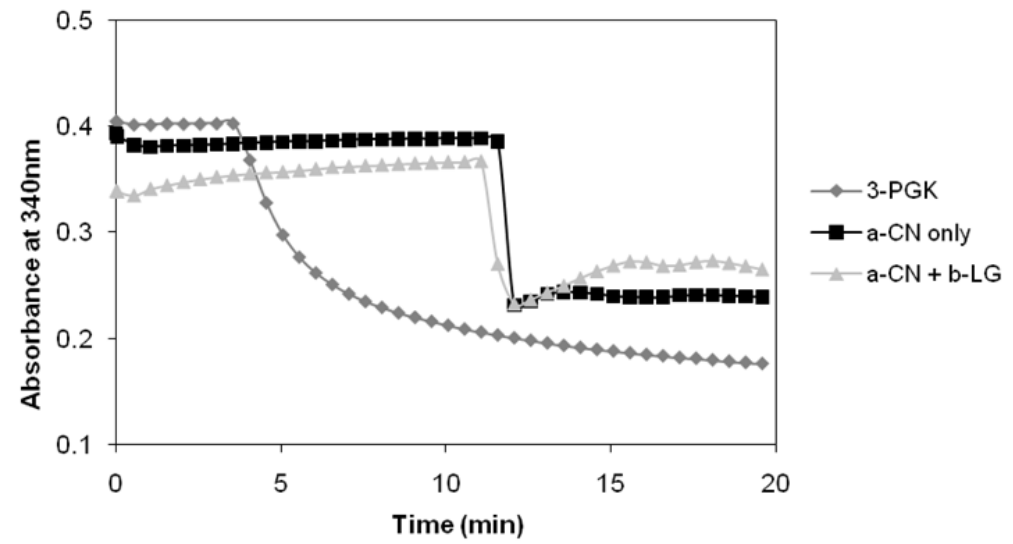

Figure 7. ATPase activity of $\alpha$ s-casein. The ability of $\alpha$-casein $(a-C N)$ to hydrolyse $170 \mu \mathrm{M}$ ATP was examined in the presence and absence of heat-stressed $\beta$-lactoglobulin (b-LG) at a ratio of 2:1 (w:w) in $50 \mathrm{mM}$ sodium phosphate buffer containing $0.2 \mathrm{M} \mathrm{NaCl}, 2.5 \mathrm{mM}$ EDTA and $0.02 \% \mathrm{NaN}_{3}$ at pH 7.2. Generation of ADP was monitored via NADH oxidation giving a decrease in absorbance at $340 \mathrm{~nm}$. This can be seen with the addition of $21 \mathrm{nmol}$ exogenous ADP at $11 \mathrm{~min}$ (black arrow) and the addition of 1.1 $\mu \mathrm{mol} 3$-phosphoglycerate to 0.76 units of 3-phosphoglycerate kinase (3-PGK) at 4 min (grey arrow). All experiments were performed in triplicate at $37^{\circ} \mathrm{C}$.

Recovery of enzyme activity was assessed using heat-stressed catalase and ADH [17, 73] in the presence and absence of $1: 1(\mathrm{w}: \mathrm{w})$ ratios of $\alpha$ s-casein similar to the assays shown in Figure 6, with the addition of Hsp70 and ATP after a recommended 30 min 'recovery period' $[17,58]$. In the presence of as-casein, neither catalase nor $\mathrm{ADH}$ showed any significant recovery from heat stress at $55^{\circ} \mathrm{C}$, with only $1( \pm 5) \%$ activity remaining 5 hours after the addition of Hsp70 and ATP. In contrast, control experiments showed $27( \pm 5) \%$ recovery of catalase activity over the same time period and under the same conditions, but with the addition of clusterin instead of as-casein [17]. This effect of clusterin has been shown to be specific for the chaperone, as other proteins added in its place (e.g. lysozyme, myoglobin) have been shown to be unable to facilitate enzyme recovery to the same extent 
[73]. It could be concluded, therefore, that the binding of Hsp70 to its target protein to achieve refolding and release, coupled with ATP binding and hydrolysis, is impeded by the manner in which as-casein binds the destabilised target protein [17]. In stabilising the heatstressed enzymes, as-casein may hold its target more tightly or incorporate them into the complex in such a way that they are not accessible to Hsp70 to allow for the refolding that has been seen for target proteins stabilised by sHsps and clusterin [58, 72, 73, 139]. It is possible that the as-casein-target protein complex is to some extent incorporated the casein micellar structure and this arrangement influences the accessibility of Hsp70 [17]. CryoEM and X-ray solution studies on sHsps have revealed that stressed $\alpha$-lactalbumin molecules coat the exterior surface of the oligomeric form of $\alpha_{\mathrm{B}}$-crystallin when the chaperone-target protein complex is formed [99, 143]. Further studies with spin-labelled melittin peptides have shown that there is a stoichiometry of approximately 1:1 [144] in the binding of the peptides to each monomer of $\alpha$-crystallin and that these are relatively evenly spaced [145]. This regular arrangement of target protein binding to $\alpha$-crystallin may be an important factor in the ability of Hsp70 to subsequently refold target proteins [17].

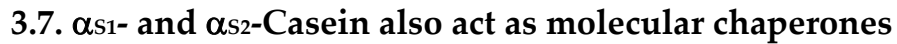

The constituent proteins of as-casein, $\alpha_{s 1-}$ and as2-casein (separated and purified as described earlier in this chapter) have been shown to exhibit chaperone action independently of one another. Like $\alpha$ s-casein, the chaperone action of $\alpha_{s 1}-$ and $\alpha_{s 2}-$ casein has been described for a range of target proteins under various stress conditions [17]. Studies with reduced insulin as the target protein showed that at ratios of $0.25: 1$ and $0.5: 1(\mathrm{w}: \mathrm{w}$ casein: insulin) both $\alpha s_{1}-$ and $\alpha$ s2-casein had comparable chaperone activity to as-casein (summarised in Table 2).

\begin{tabular}{|c|c|c|c|}
\hline$\alpha-C N:$ insulin (w:w) & $\alpha s-C N$ & $\alpha_{s 1}-\mathrm{CN}$ & $\alpha_{s 2}-\mathrm{CN}$ \\
\hline $\begin{array}{l}0.1: 1 \\
\end{array}$ & $66( \pm 2) \%$ & $49( \pm 2) \%$ & $64( \pm 2) \%$ \\
\hline $0.25: 1$ & $74( \pm 0.6) \%$ & $69( \pm 2) \%$ & $73( \pm 1) \%$ \\
\hline $0.5: 1$ & $96( \pm 0.4) \%$ & $91( \pm 1) \%$ & $91( \pm 0.3) \%$ \\
\hline $1: 1$ & $98( \pm 0.9) \%$ & $98( \pm 0.1) \%$ & $97( \pm 0.4) \%$ \\
\hline
\end{tabular}

Table 2. Summary of chaperone assay data with insulin under reduction stress in the presence of increasing amounts of $\alpha_{s-}, \alpha_{s 1-}$ or $\alpha_{s 2}-\mathrm{CN}$. Figures shown are \% protection of stressed target protein by the chaperone. Percentage protection is calculated as previously described. Reprinted with permission from [17]. Copyright (2011) Elsevier Inc.

When assessed with catalase under heat stress, a 0.5:1 ratio of $\alpha$ s-casein to catalase provided $88( \pm 2) \%$ protection after $50 \mathrm{~min}$. Under these conditions, as2-casein was the better chaperone, giving $84( \pm 4) \%$ protection at the same ratio and time point, whereas as1-casein provided only $64( \pm 1) \%$ at the same ratio and time point [17]. In another set of experiments that included $0.1 \mathrm{M} \mathrm{NaCl}$ in order to more accurately simulate the high salt conditions in milk, catalase aggregation occurred more rapidly and as a result, all of the $\alpha$-casein proteins tested were less effective in preventing catalase aggregation and precipitation. These results are summarised in Table 3 and visible spectroscopy spectra are shown in Figure 8. 


\begin{tabular}{|c|c|c|c|c|c|c|}
\hline $\begin{array}{c}\alpha-C N: c a t \\
(\mathbf{w : w )}\end{array}$ & $\alpha s-\mathrm{CN}$ & $\alpha s 1-C N$ & $\alpha s 2-\mathrm{CN}$ & $\begin{array}{c}\alpha s-\mathrm{CN}+ \\
\text { salt }\end{array}$ & $\begin{array}{c}\alpha s 1-\mathrm{CN}+ \\
\text { salt }\end{array}$ & $\begin{array}{c}\alpha s 2-\mathrm{CN}+ \\
\text { salt }\end{array}$ \\
\hline $0.25: 1$ & $76( \pm 1) \%$ & $44( \pm 9) \%$ & $77( \pm 3) \%$ & $15( \pm 0.1) \%$ & $3( \pm 0.8) \%$ & $16( \pm 2) \%$ \\
\hline $0.5: 1$ & $88( \pm 2) \%$ & $64( \pm 1) \%$ & $84( \pm 4) \%$ & $27( \pm 1) \%$ & $16( \pm 2) \%$ & $26( \pm 2) \%$ \\
\hline $1: 1$ & $96( \pm 2) \%$ & $80( \pm 3) \%$ & $85( \pm 6) \%$ & $57( \pm 1) \%$ & $16( \pm 3) \%$ & $18( \pm 2) \%$ \\
\hline
\end{tabular}

Table 3. Summary of chaperone assay data with catalase (cat) under heat stress in the presence of increasing amounts of $\alpha_{s-}, \alpha_{s 1}-$ or $\alpha_{s 2}-\mathrm{CN}$ and in the presence and absence of $0.1 \mathrm{M} \mathrm{NaCl}$. Figures shown are $\%$ protection of stressed target protein by the chaperone. Percentage protection is calculated as previously described. Reprinted with permission from [17]. Copyright (2011) Elsevier Inc.

Under conditions of added salt, the chaperone abilities of $\alpha_{s-}, \alpha_{s 1}-$ and $\alpha_{s 2}-$ casein were all greatly reduced, with a 0.5 : 1 ratio of $\alpha$ s-casein: catalase providing only $27( \pm 1) \%$ protection, compared with $88( \pm 2) \%$ for the same ratio in the absence of salt. At the same ratio and time point as2-casein showed similar chaperone ability to as-casein (26 $( \pm 2) \%$ protection), with the most profoundly affected protein being as1-casein. Under these conditions, even a 1:1 ratio of as1-casein: catalase provided only $16( \pm 2) \%$ protection. Analysis of the samples from these assays by SDS-PAGE showed that as1-casein had actually formed high molecular weight complexes that failed to migrate through the gel matrix to any extent, but like the other chaperones, remained soluble [17]. Despite remaining in solution, the data show that this aggregated form of $\alpha$ s1-casein was no longer an effective chaperone. The self-association of as1-casein in the presence of salt most likely occurs as a result of neutralisation of charged residues on the protein ('charge screening' [146]) by the interaction with sodium and chloride ions i.e. the early stages of isoelectric precipitation [12]. Aromatic residues in $\alpha$ s1- $^{-}$ casein are also thought to play a major role in the hydrophobic interactions between as1casein molecules, which at increasing ionic strengths go from monomers to dimers, tetramers, hexamers, octamers, then higher order aggregates [147].

Molecular chaperones are known to stabilise amorphously aggregating proteins like those described above, but they also interact with and stabilise proteins destined to form fibrillar aggregates (refer to Figure 4). This property has been described for sHsps in suppressing amyloid fibril formation in $\beta$-amyloid peptide [148, 149], apolipoprotein C-II [150] and in $\alpha$ synuclein, the protein present in the Lewy bodies of Parkinson's disease [151]. A form of $\kappa-$

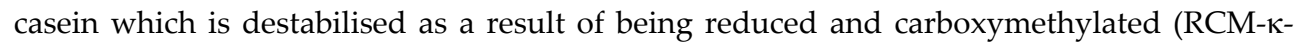
casein) has been shown to form fibrils at $37^{\circ} \mathrm{C}$ in the presence of DTT and has been widely used as a model for investigating chaperone action against fibrillar proteins [28, 33, 79, 152].

Studies have shown that the presence of a $\sim 0.6: 1 \mathrm{w}: \mathrm{w}$ ratio of $\alpha$ s-casein:RCM- $\kappa$-casein reduced the Thioflavin $\mathrm{T}$ fluorescence (an indicator of the probe's binding to forming fibrils) by $65 \%$, and in the presence of a 2.5:1 w:w ratio of $\alpha$ s-casein:RCM- $\kappa$-casein, fibril formation was completely abrogated $[17,28]$. In the presence of $\alpha s_{1}-$ or $\alpha s_{2}$-casein at the same ratio, fibril formation was also completely suppressed. At lower ratios however i.e. $~ 0.6: 1 \mathrm{w}: \mathrm{w} \alpha-$

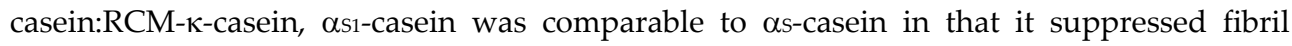
formation by $96 \%$, but $\alpha$ s2-casein was able to only provide $56 \%$ protection under the same conditions as shown in Figure 9 [17]. 

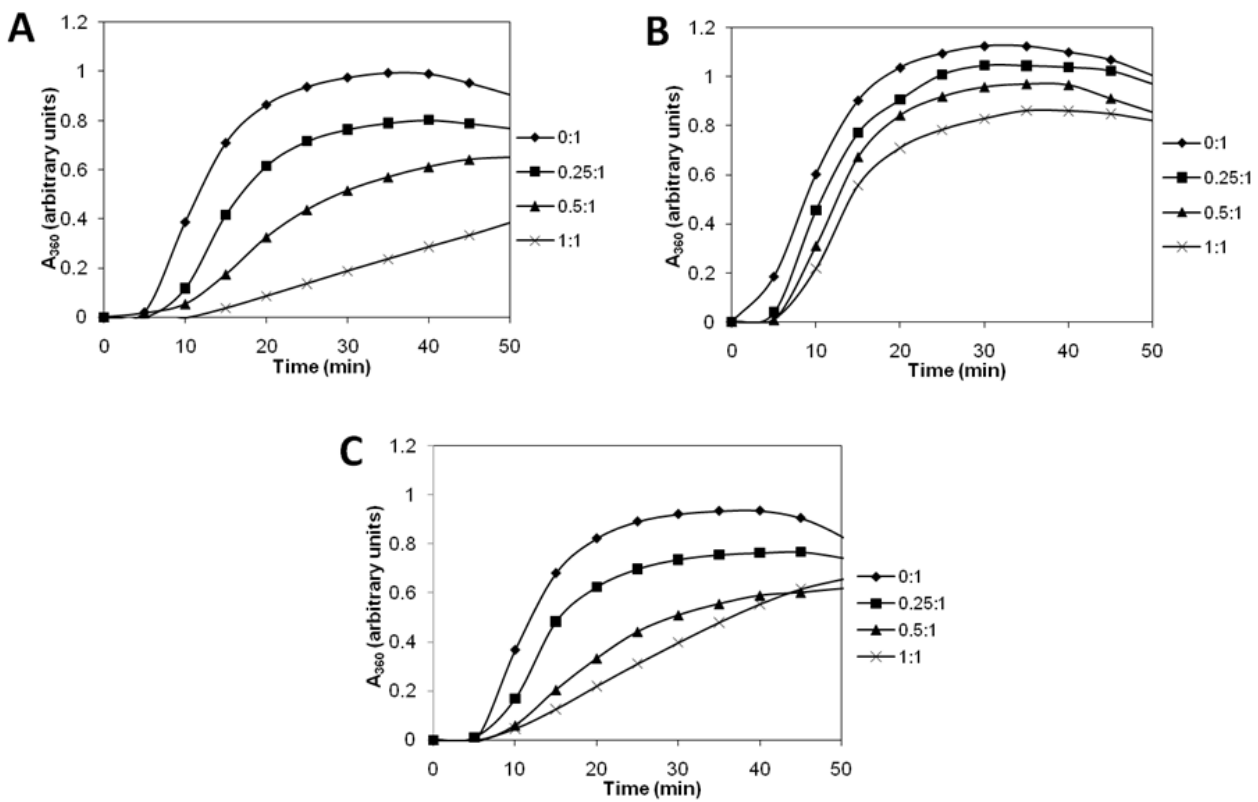

Figure 8. Chaperone activity of A) $\alpha s_{-}$, B) $\alpha s_{1}-$ and C) $\alpha s_{2}-$ casein against amorphously aggregating catalase, in the presence of $0.1 \mathrm{M} \mathrm{NaCl}$ and various $\mathrm{w}: \mathrm{w}$ ratios as determined by light scattering at 360 $\mathrm{nm}$. The $0: 1$ ratio in each assay represents catalase aggregation in the absence of $\alpha$-casein i.e. no chaperone present. Reprinted with permission from [17]. Copyright (2011) Elsevier Inc.

The results of the fibril-forming experiments discussed above were further confirmed by TEM studies (Figure 10) which showed that the presence of a 1.25:1 ratio of as1-casein resulted in reduced numbers of fibrils being formed by RCM- $\kappa$-casein (Figure 10B). In addition, those fibrils that were formed were shorter in length than those observed for RCM- $\kappa$-casein in the absence of chaperone (Figure 10A). Conversely, in the presence of the

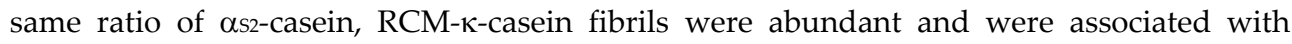
rounded aggregates 50-100 $\mathrm{nm}$ in diameter (Figure 10C) that may have contained one or both proteins. as2-Casein, which forms characteristic twisted fibrils, was included as a control at the same concentration but in the absence of chaperone [17].

Previous studies have shown that both $\beta$ - and $\alpha$ s-casein have the ability to inhibit the formation of fibrils by $\kappa$-casein [28], and this observation has led to the conclusion that amyloid formation in mixtures of casein (i.e. whole casein), namely by $\alpha_{\mathrm{s} 2-}$ and $\kappa$-casein, is prevented by the action of the casein chaperones, $\beta$ - and $\alpha_{s 1}$-casein. As $\alpha s 1$-casein was a more potent inhibitor of fibril formation than $\alpha$ s2-casein under these conditions, it would be reasonable to assume that a large proportion of the fibril-preventing action of as-casein is provided by as1-casein. As previously discussed, the chaperone activity of as1-casein against amorphously aggregating catalase in the presence of salt was a stark contrast, but provides the rationale that perhaps in milk, where salt concentrations are high, as1-casein 
has an important role in preventing fibrillar aggregation rather than amorphous aggregation [17].
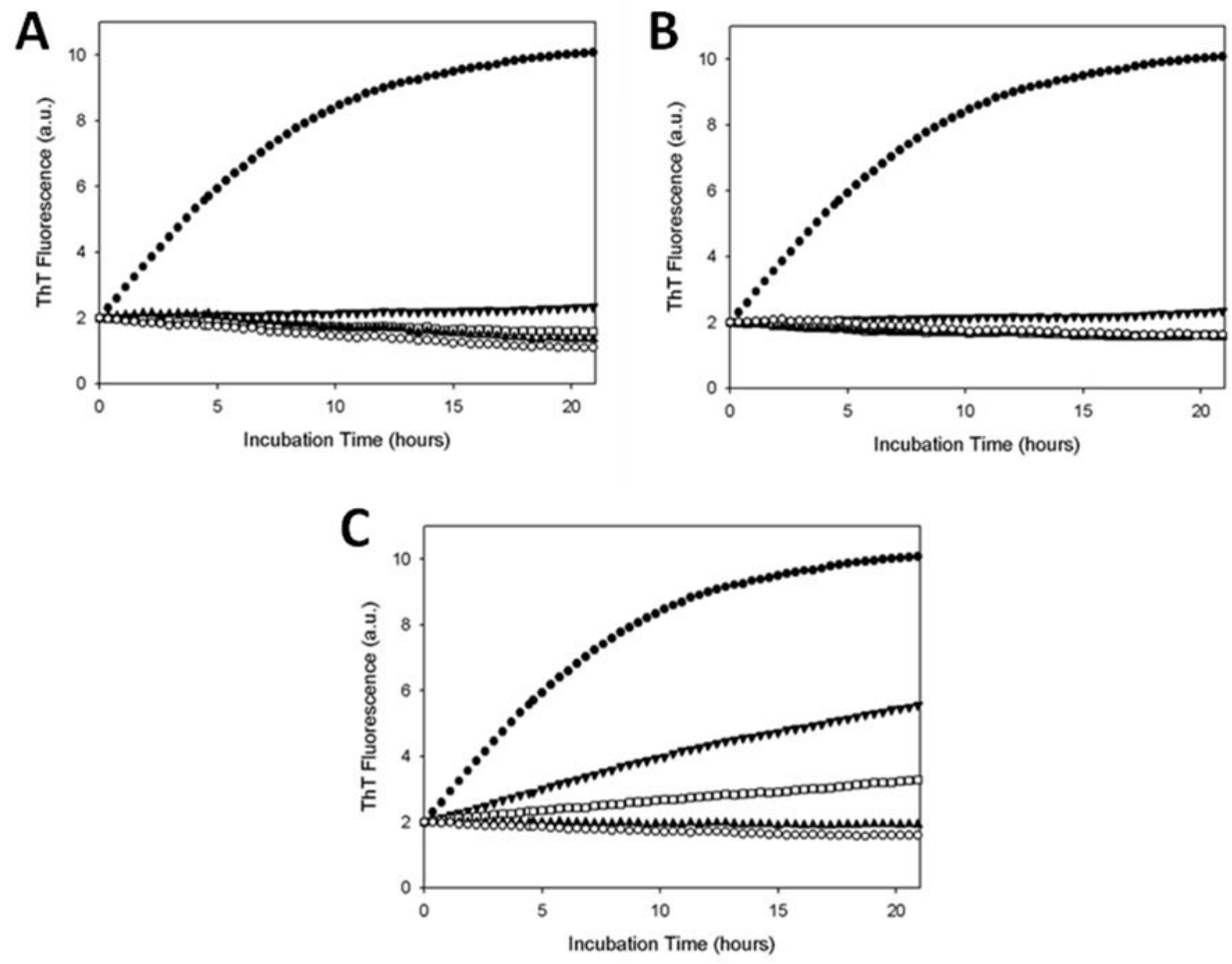

Figure 9. Chaperone activity of A) $\alpha s_{-}$, B) $\alpha s_{1}-$ and C) $\alpha s_{2}$-casein against amyloid forming RCM- $\kappa$-casein as determined by Thioflavin T (ThT) fluorescence. Ratios of chaperone:RCM- $\kappa$-casein equivalent to $\sim 0.6: 1,1.25: 1$ and 2.5:1 (w:w) are represented by $\boldsymbol{\nabla}, \square$ and $\boldsymbol{\Lambda}$, respectively. Reprinted with permission from [17]. Copyright (2011) Elsevier Inc.

Investigations into the mechanism of $\alpha$ s-casein's chaperone action are only in their infancy, and the precise nature of its chaperone function remains largely an enigma. Despite this, comparisons with the chaperone action of sHsps have provided several important insights. In sHsps, binding of a stressed target protein is thought to occur primarily via hydrophobic interactions between exposed hydrophobic regions on the chaperone and on the partially unfolded protein [139]. It has been well described that under conditions of heat stress, some sHsps undergo a conformational change which increases the extent of exposed hydrophobicity and these structural changes are accompanied by functional ones i.e. increased chaperone action [94, 125, 127, 153, 154]. Solubility of the large sHsp aggregates is maintained by hydrophilic regions of the chaperone that are dynamic and solvent-exposed, such as the flexible C-terminal extensions in $\alpha$-crystallin [70, 93]. The presence of these polar regions is also believed to be important in maintaining the solubility of the target-protein- 
chaperone complex once interaction between the two proteins has taken place, resulting in a high molecular weight complex [155]. It is plausible that as-casein has a similar mode of action. The distribution of hydrophobic and hydrophilic residues in the caseins is not uniform and their lack of well-defined structure encourages self-association but also likely aids in chaperone action with partially unfolded target proteins. Within the predominant ascasein subunit, as1-casein, hydrophobic residues are clustered into three distinct regions (residues 1-44, 90-113 and 132-199) and the hydrophilic phosphoserine residues are also clustered in the polar domains (residues 41-80) [5]. It is possible that the structure of $\alpha$ s1- $^{-}$ casein is similar to that of the sHsps whereby it has a predominant, relatively globular hydrophobic domain linked to a highly polar region akin to the flexible polar C-terminal extension of the sHsps [155-157]. Hypothetical structures for as-casein subunits obtained through energy minimisation calculations are consistent with this model [15]. The most

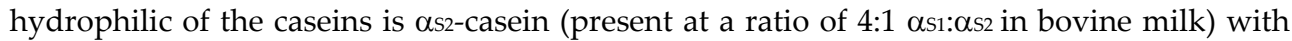
only two areas of hydrophobicity arising from residues 160-207 and 90-120 [17]. The Cterminal region of as2-casein possesses a high net charge despite being relatively hydrophobic [5].
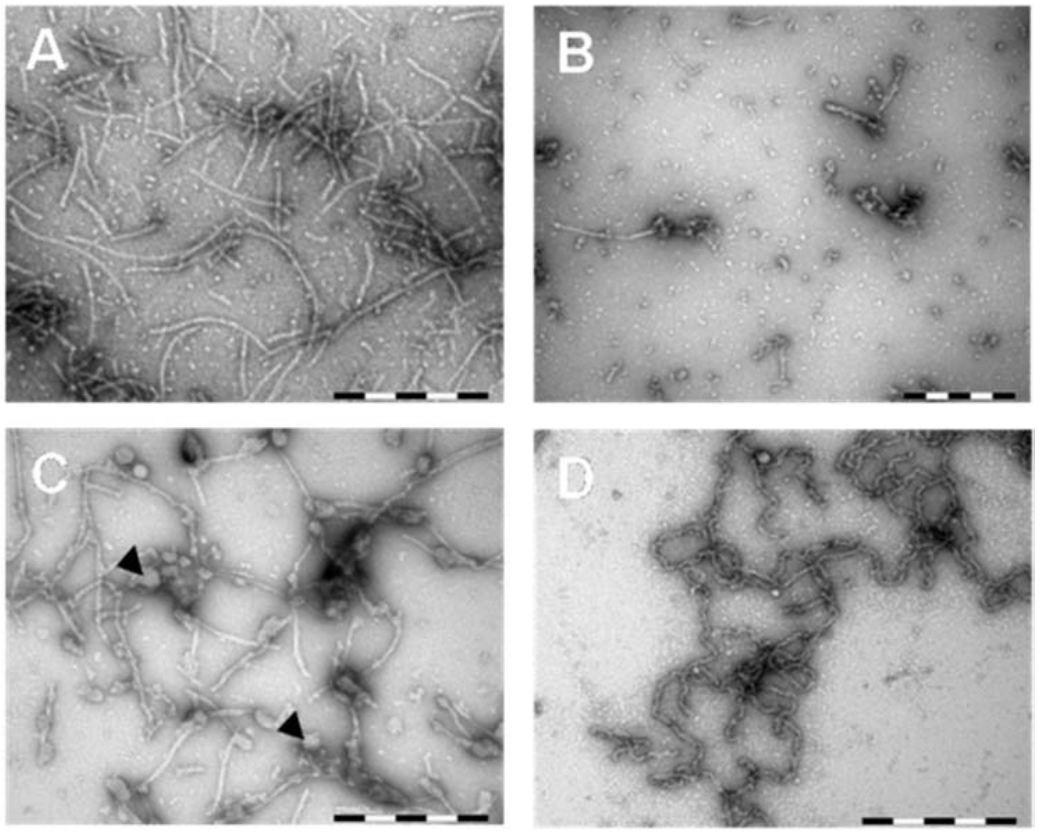

Figure 10. Electron micrographs of RCM-к-casein incubated for $50 \mathrm{~h}$ at $37^{\circ} \mathrm{C}$ with and without $\alpha$ s-casein proteins. RCM- $\kappa$-casein incubated in the absence (A) or presence of $\sim 1.0 \mathrm{~mol}: \mathrm{mol}$ ratio $(3.75 \mathrm{mg} / \mathrm{mL})$ of either as1-casein (B) or as2-casein (C). as2-Casein alone is also shown (D; $3.75 \mathrm{mg} / \mathrm{mL})$. In (C), small, rounded aggregates are indicated by 4 . Scale bars represent $500 \mathrm{~nm}$. Reprinted with permission from [17]. Copyright (2011) Elsevier Inc. 
Size-exclusion HPLC studies have shown that $\alpha$ s-casein exists as a polydisperse aggregate [18] and it is likely that this heterogeneity arises from association of the two subunits. It is apparent from Figure 4 and from the previous discussion of the chaperone mechanism of sHsps that a crucial part of the process is the dynamic interaction between large, heterogeneous aggregates formed by as-casein and smaller oligomers, which, in the case of the sHsps, are believed to be the active form of the chaperone $[18,110]$. As the other casein proteins present in milk ( $\beta$-, and $\kappa$-casein) have also been shown to possess chaperone activity [18, 33, 110-112] it is likely that these subunits also play an important role in dynamic subunit exchange and stabilisation of the casein aggregate. The ability of as-casein to resolubilise aggregated target protein species is especially interesting in the context of the mechanism shown in Figure 4. The data on insulin resolubilisation by as-casein indicates that an equilibrium certainly exists between intermediately folded states of target proteins (e.g. $\mathrm{I}_{2}$ ) and their amorphous aggregates, but that in addition, $\alpha$ s-casein is capable of pushing this equilibrium back toward a more soluble and therefore more stable state ( $\mathrm{I}_{1}$ or $\mathrm{I}_{2}$ ) following formation of the aggregate. Dynamic equilibrium between the $\alpha$ s-casein aggregate and smaller, dissociated species is likely to be important in this aspect of its chaperone function, but this remains to be elucidated.

\section{Conclusion and future directions}

The predominant milk protein, as-casein, has been shown to possess molecular chaperone abilities with a range of target proteins, under different stress conditions. Like the sHsps, ascasein is also ATP-independent in its chaperone action. As described in this chapter, ascasein and its two constituent proteins, as1- and as2-casein are capable of interacting with and stabilising a range of physiological and non-physiological target proteins. This 'promiscous' nature is a feature of many other chaperones. Under a variety of stress conditions, as-, as1- and as2-casein form high molecular weight complexes with partially unfolded target proteins, stabilising them against precipitation, whether this be via amorphous or fibrillar pathways.

Like the sHsps and clusterin, the $\alpha$-casein proteins exhibit different degrees of chaperone activity depending on the mode of target protein aggregation (i.e. amorphous versus fibrillar), the rate of target protein aggregation, the size of the target protein, the conditions of stress applied and the presence of competing ions (e.g. salt). Unlike the sHsps (specifically Hsp25 and $\alpha$-crystallin) and clusterin, however, $\alpha$-casein binds target proteins in a manner that does not allow subsequent interaction and reactivation by the ATPdependent Hsp70.

The mechanism/s by which $\alpha$ s-casein stabilises and prevents the precipitation of other proteins in milk (such as the other caseins and whey proteins such as $\alpha$-lactoglobulin and $\beta$ casein) is of interest to the dairy industry as it may provide an alternative method for longlife milk treatment [18]. It has been demonstrated that $\alpha$ s-casein, and indeed other caseins such as $\beta$-casein, interact with 'molten globule' states or folding intermediates of proteins. As suggested by others, processing treatments in dairy foods have the potential to transform 
previously native structures into denatured or partially denatured states and that the presence of these states may either present a problem or offer opportunities for novel foods to be developed [123]. This is where the action of molecular chaperones may play an important role. Thus, a better understanding of the aggregation processes in milk and how these can be modified opens up potential avenues for new milk based products with novel textures and other organoleptic properties to be developed.

\section{Author details}

Teresa Treweek

Graduate School of Medicine, University of Wollongong, Australia

\section{Acknowledgement}

The author gratefully acknowledges the financial support of Dairy Australia for much of the work presented here. Sincere thanks also go to Prof. Will Price, Prof. John Carver, Dr Heath Ecroyd and Dr David Thorn for their assistance with the preparation of this manuscript.

\section{References}

[1] Swaisgood HE. Chemistry of the caseins. In: Fox PF. (ed.) Advanced Dairy Chemistry- 1: Proteins. London: Elsevier Applied Science; 1992. p63-110.

[2] Fox PF, McSweeney PLH. Dairy chemistry and biochemistry. London: Blackie Academic and Professional; 1998.

[3] Holt C, Sawyer L. Caseins as rheomorphic proteins: Interpretations of the primary and secondary structures of the alphaS1-, beta- and kappa-caseins. Journal of the Chemical Society, Faraday Transactions 1993; 89 2683-2692.

[4] Swaisgood HE. Chemistry of the caseins. In: Fox PF, McSweeney PLH (eds.) Advanced Dairy Chemistry - 1: Proteins. 3rd ed., Part B. New York: Kluwer Academic/Plenum Publishers; 2003. p. 139-201.

[5] Fox PF. Milk Proteins: General and historical aspects. In: Fox PF, McSweeney PLH. (eds.) Advanced Dairy Chemistry - 1: Proteins. 3rd ed., Part B. New York: Kluwer Academic/Plenum Publishers; 2003. p1-48.

[6] Aschaffenburg R, Drewry J. Occurrence of different beta-lactoglobulins in cow's milk. Nature 1955;176(4474) 1309-1314.

[7] Ng Kwai-Hang KF, Grosclaude F. Genetic polymorphism of milk protein. In: Fox PF. (ed.) Advanced Dairy Chemistry - 1: Proteins. London: Elsevier Applied Science; 1992. p405-455.

[8] Jakob E, Puhan Z. Technological properties of milk as influenced by genetic polymorphism of dairy proteins. A review. International Dairy Journal 1992;2 157-178.

[9] Eigel WN, Butler JE, Ernstrom CA, Farrell HMJ, Harwalkar VR, Jenness R, McLWhitney R. Nomenclature of proteins of cow's milk: Fifth revision. Journal of Dairy Science 1984;67 1599-1631. 
[10] Dunker AK, Brown CJ, Lawson JD, Iakoucheva LM, Obradovic Z. Intrinsic disorder and protein function. Biochemistry 2002;41(21) 6573-6582.

[11] Uversky VN. What does it mean to be natively unfolded? European Journal of Biochemistry 2002;269(1) 2-12.

[12] Alaimo MH, Farrell HMJ, Germann MW. Conformational analysis of the hydrophobic peptide as1-casein(136-196). Biochimica et Biophysica Acta 1999;1431 410-420.

[13] Kuwajima K. The molten globule state of $\alpha$-lactalbumin. The FASEB Journal 1996;10 102-109.

[14] Kumosinski TF, Brown EM, Farrell HMJ. Three-dimensional molecular modeling of bovine caseins: a refined, energy-minimized $\kappa$-casein structure. Journal of Dairy Science 1993;76(9) 2507-2520.

[15] Kumosinski TF, Brown FM, Farrell HMJ. Three-dimensional molecular modeling of bovine caseins: as1-casein. Journal of Dairy Science 1991;74 2889-2895.

[16] Kumosinski TF, King G, Farrell HMJ. An energy-minimized casein submicelle working model. Journal of Protein Chemistry 1994;13(8) 681-700.

[17] Treweek TM, Thorn DC, Price WE, Carver JA. The chaperone action of bovine milk as1and as2-caseins and their associated form as-casein. Archives of Biochemistry and Biophysics 2011;510 42-52.

[18] Morgan PE, Treweek TM, Lindner RA, Price WE, Carver JA. Casein proteins as molecular chaperones. Journal of Agricultural and Food Chemistry 2005;53(7) 26702683.

[19] Holt C, Carver JA. Darwinian transformation of a 'scarcely nutritious fluid' into milk. Journal of Evolution Biology 2012;In press.

[20] Holt C, Dalgleish DG. Electrophoretic and hydrodynamic properties of bovine casein micelles interpreted in terms of particles with an outer hairy layer. Journal of Colloid Interface Science 1986;114 513-524.

[21] Marchin S, Putaux JL, Pignon F, Leonil J. Effects of the environmental factors on the casein micelle structure studied by cryo transmission electron microscopy and smallangle $x$-ray scattering/ultrasmall-angle x-ray scattering. The Journal of Chemical Physics 2007;126(4) 045101.

[22] McMahon DJ, McManus WR. Rethinking casein micelle structure using electron microscopy. Journal of Dairy Science 1998;81 2985-2993.

[23] McMahon DJ, Oommen BS. Supramolecular structure of the casein micelle. Journal of Dairy Science 2008;91(5) 1709-1721.

[24] Knudsen JC, Skibsted LH. High pressure effects on the structure of the casein micelles in milk as studied by cryo-transmission electron microscopy. Food Chemistry 2010;119 202-208.

[25] Dalgleish DG. On the structural models of bovine casein micelles - review and possible improvements. Soft Matter 2011;7 2265-2272.

[26] DeKruif CG, Holt C. Casein micelle structure, functions and interactions. In: Fox PF, McSweeney PLH. (eds.). Advanced Dairy Chemistry - 1: Proteins. 3rd ed., Part B. New York: Kluwer Academic/Plenum Publishers; 2003. p233-276. 
[27] Farrell HMJ, Cooke PH, Wickham ED, Piotrowski EG, Hoagland PD. Environmental influences on bovine $\kappa$-casein: reduction and conversion to fibrillar (amyloid) structures. Journal of Protein Chemistry 2003;22(3) 259-273.

[28] Thorn DC, Meehan S, Sunde M, Rekas A, Gras SL, MacPhee CE, Dobson CM, Wilson MR, Carver JA. Amyloid fibril formation by bovine milk kappa-casein and its inhibition by the molecular chaperones $\alpha$ s- and $\beta$-casein. Biochemistry 2005;44(51) 17027-17036.

[29] Thorn DC, Ecroyd H, Sunde M, Poon S, Carver JA. Amyloid fibril formation by bovine milk $\alpha$ s2-casein occurs under physiological conditions yet is prevented by its natural counterpart, as1-casein. Biochemistry 2008;47(12) 3926-3936.

[30] Leonil J, Henry G, Jouanneau D, Delage MM, Forge V, Putaux JL. Kinetics of fibril formation of bovine $\kappa$-casein indicate a conformational rearrangment as a critical step in the process. Journal of Molecular Biology 2008;381 1267-1280.

[31] Syme CD, Blanch EW, Holt C, Jakes R, Goedert M, Hecht L, Barron L. A Raman optical activity study of rheomorphism in caseins, synuclein and tau. New insight into the structure and behaviour of natively unfolded proteins. European Journal of Biochemistry 2002;269 148-156.

[32] Blanch EW, Morozova-Roche LA, Cochran DA, Doig AJ, Hecht L, Barron LD. Is polyproline II helix the killer conformation? A raman optical activity study of the amyloidogenic perfibrillar intermediate of human lysozyme. Journal of Molecular Biology 2000;301(2) 553-563.

[33] Thorn DC, Ecroyd H, Carver JA. The two-faced nature of milk casein proteins: amyloid fibril formation and chaperone-like activity. Australian Journal of Dairy Technology 2009;64(1) 34-40.

[34] Thompson MP. DEAE-cellulose-urea chromatography of casein in the presence of 2mercaptoethanol. Journal of Dairy Science 1966;49(7) 792-795.

[35] Creamer LK, Richardson T, Parry DAD. Secondary structure of bovine $\alpha$ s1- and $\beta$-casein in solution. Archives of Biochemistry and Biophysics 1981;211 689-693.

[36] Haga M, Yamauchi K, Aoyagi S. Conformation and some properties of bovine as2-group casein. Agricultural and Biological Chemistry 1983;47(7) 1467-1471.

[37] Hoagland PD, Unruh JJ, Wickham ED, Farrell HMJ. Secondary structure of bovine as2casein: Theoretical and experimental approaches. Journal of Dairy Science 2001;84 19441949.

[38] Chakraborty A, Basak S. pH-induced structural transitions of caseins. Journal of Photochemistry and Photobiology 2007;87 191-199.

[39] Sreerama N, Woody RW. A self-consistent method for the analysis of protein secondary structure from circular dichroism. Analytical Biochemistry 1993;209(1) 32-44.

[40] Sreerama N, Woody RW. Estimation of protein secondary structure from circular dichroism spectra: Comparison of CONTIN, SELCON, and CDSSTR methods with an expanded reference set. Analytical Biochemistry 2000;287 252-260.

[41] Lobley A, Whitmore L, Wallace BA. DICHROWEB: A website for the analysis of protein secondary structure from circular dichroism spectra. Biophysical Journal 2001;80 373a. 
[42] Lobley A, Whitmore L, Wallace BA. DICHROWEB: an interactive website for the analysis of protein secondary structure from circular dichroism spectra. Bioinformatics 2002;18(1) 211-212.

[43] Whitmore L, Wallace BA. DICHROWEB: an online server for protein secondary structure analyses from circular dichroism spectroscopic data. Nucleic Acids Research 2004;32 W668-673.

[44] Anfinsen CB, Haber E, Sela M, White FHJ. The kinetics of formation of native ribonuclease during oxidation of the reduced polypeptide chain. Proceedings of the National Academy of Sciences, U.S.A. 1961;47(9) 1309-1314.

[45] Buchner J. Supervising the fold: functional principles of molecular chaperones. The FASEB Journal 1996;10 10-19.

[46] Anfinsen CB. The formation and stabilization of protein structure. Biochemical Journal 1972;128(4) 737-749.

[47] Anfinsen CB. Principles that govern the folding of protein chains. Science 1973;181(96) 223-230.

[48] Rudolph R, Lilie H. In vitro folding of inclusion body proteins. The FASEB Journal 1996;10(1) 49-56.

[49] Ptitsyn OB. How does protein synthesis give rise to the 3D-structure? FEBS Letters 1991;285(2) 176-181.

[50] Fink AL. Molten globules. In: Shirley BA. (ed.) Methods in Molecular Biology. New Jersey: Humana Press Inc.; 1995.

[51] Jaenicke R, Creighton TE. Junior chaperones. Current Biology 1993;3(4) 234-235.

[52] Ewbank JJ, Creighton TE, Hayer-Hartl M-K, Hartl FU. What is the molten globule? Nature Structural and Molecular Biology 1995;2(1) 10-11.

[53] Ellis RJ, Hartl FU. Protein folding in the cell: competing models of chaperonin function. The FASEB Journal 1996;10 20-26.

[54] Wright PE, Dyson HJ. Insights into the structure and dynamics of unfolded proteins from nuclear magnetic resonance. Advances in Protein Chemistry 2002;62 311-340.

[55] Lindner RA, Kapur A, Carver JA. The interaction of the molecular chaperone, $\alpha-$ crystallin, with molten globule states of bovine $\alpha$-lactalbumin. Journal of Biological Chemistry 1998;272 27722-27729.

[56] Thomas PJ, Qu B-H, Pedersen PL. Defective protein folding as a basis of human disease. Trends in Biochemical Sciences 1995;20 456-459.

[57] Welch WJ, Brown CR. Influence of molecular and chemical chaperones on protein folding. Cell Stress and Chaperones 1996 April 1996;1(2) 109-115.

[58] Ehrnsperger M, Graber S, Gaestel M, Buchner J. Binding of non-native protein to Hsp25 during heat shock creates a reservoir of folding intermediates for reactivation. EMBO Journal 1997;16(2) 221-229.

[59] Ellis RJ, van der Vies SM. Molecular Chaperones. Annual Review of Biochemistry 1991;60 321-347.

[60] Jakob U, Buchner J. Assisting spontaneity: the role of Hsp90 and small Hsps as molecular chaperones. Trends in Biochemical Sciences 1994;19(5) 205-211. 
[61] Ruddon RW, Bedows E. Assisted protein folding. Journal of Biological Chemistry 1997;272(6) 3125-3128.

[62] Kim PS, Arvan P. Calnexin and BiP act as sequential molecular chaperones during thyroglobulin folding in the endoplasmic reticulum. Journal of Cell Biology 1995;128(12) 29-38.

[63] Frydman J, Hartl FU. Principles of chaperone-assisted protein folding: differences between in vitro and in vivo mechanisms. Science 1996;272(526) 1497-1502.

[64] Martin J, Langer T, Boteva R, Schramel A, Horwich AL, Hartl FU. Chaperonin-mediated protein folding at the surface of groEL through a 'molten globule'-like intermediate. Nature 1991;352(6330) 17-18.

[65] Ingolia TD, Craig EA, McCarthy BJ. Sequence of three copies of the gene for the major Drosophila heat shock induced protein and their flanking regions. Cell 1980;21(3) 669676.

[66] Hunt C, Morimoto R. Conserved features of eukaryotic hsp70 genes revealed by comparison with the nucleotide sequence of human hsp70. Proceedings of the National Academy of Sciences, U.S.A. 1985;82(19) 6455-6459.

[67] Corces V, Holmgren R, Freund R, Morimoto R, Meselson M. Four heat shock proteins of Drosophila melanogaster coded within a 12-kilobase region in chromosome subdivision 67B. Proceedings of the National Academy of Sciences, U.S.A. 1980;77 5390-5393.

[68] Lindquist S. The Heat Shock Response. Annual Review of Biochemistry 1986;55 11511191.

[69] Lindquist S, Craig EA. The heat-shock proteins. Annual Review of Genetics 1988;22 631677.

[70] Treweek TM, Morris AM, Carver JA. Intracellular protein unfolding and aggregation: The role of small heat-shock chaperone proteins. Australian Journal of Chemistry 2003;56 357-367.

[71] Wang K, Spector A. The chaperone activity of bovine $\alpha$-crystallin. Interaction with other lens crystallins in native and denatured states. Journal of Biological Chemistry 1994;269(18) 13601-13608.

[72] Wang K, Spector A. $\alpha$-Crystallin prevents irreversible protein denaturation and acts cooperatively with other heat-shock proteins to renature the stabilized partially denatured protein in an ATP-dependent manner. European Journal of Biochemistry 2000;267 4705-4712.

[73] Poon S, Easterbrook-Smith SB, Rybchyn MS, Carver JA, Wilson MR. Clusterin is an ATP-independent chaperone with very broad substrate specificity that stabilizes stressed proteins in a folding-competent state. Biochemistry 2000;39 15953-15960.

[74] Wang K, Spector A. ATP causes small heat shock proteins to release denatured protein. European Journal of Biochemistry 2001;268 6335-6345.

[75] Kappe G, Franck E, Verschuure P, Boelens WC, Leunissen JA, de Jong WW. The human genome encodes $10 \alpha$-crystallin-related small heat shock proteins: HspB1-10. Cell Stress and Chaperones 2003;8(1) 53-61. 
[76] Fontaine JM, Rest JS, Welsh MJ, Benndorf R. The sperm outer dense fiber protein is the 10th member of the superfamily of mammalian small stress proteins. Cell Stress and Chaperones 2003;8(1) 62-69.

[77] Humphreys DT, Carver JA, Easterbrook-Smith SB, Wilson MR. Clusterin has chaperone-like activity similar to that of small heat shock proteins. Journal of Biological Chemistry 1999;274(11) 6875-6881.

[78] Kapron JT, Hilliard GM, Lakins JN, Tenniswood MPR, West KA, Carr SA, Crabbe JW. Identification and characterization of glycosylation sites in human serum clusterin. Protein Science 1997;6(10) 2120 - 2133.

[79] Treweek TM, Ecroyd H, Williams DM, Meehan S, Carver JA, Walker MJ. Site-directed mutations in the C-terminal extension of human $\alpha \mathrm{B}$-crystallin affect chaperone function and block amyloid fibril formation. Public Library of Science One 2007;e1046(10) 1-10.

[80] Ecroyd H, Meehan SM, Horwitz J, Aquilina JA, Benesch JLP, Robinson CV, MacPhee $\mathrm{CE}$, Carver JA. Mimicking phosphorylation of $\alpha \mathrm{B}$-crystallin affects its chaperone activity. Biochemical Journal 2007; 401(1) 129-141.

[81] Ecroyd H, Carver JA. Crystallin proteins and amyloid fibrils. Cell and Molecular Life Sciences 2009;66(1) 62-81.

[82] Boelens WC, de Jong WW. $\alpha$-Crystallins, versatile stress proteins. Molecular Biology Reports 1995;21 75-80.

[83] Harding JJ. Cataract: Biochemistry, epidemiology and pharmacology. London: Chapman and Hall; 1991.

[84] Delaye M, Tardieu A. Short-range order of crystallin proteins accounts for eye lens transparency. Nature 1983;302 415-417.

[85] Tardieu A, Delaye M. Eye lens proteins and transparency: from light transmission theory to solution X-ray structural analysis. Annual Review of Biophysics and Biophysical Chemistry 1988;17 47-70.

[86] Veretout F, Delaye M, Tardieu A. Molecular basis of eye lens transparency. Osmotic pressure and X-ray analysis of $\alpha$-crystallin solutions. Journal of Molecular Biology 1989;205 713-728.

[87] Bhat SP, Nagimeni CN. $\alpha$ B-subunit of lens specific $\alpha$-crystallin is present in other ocular and non-ocular tissue. Biophysical and Biochemical Research Communications 1989;158(1) 319-325.

[88] Iwaki T, Kume-Iwaki A, Goldman JE. Cellular distribution of $\alpha$ B-crystallin in nonlenticular tissues. Journal of Histochemistry and Cytochemistry 1990;38(1) 31-39.

[89] Kato K, Shinohara H, Kurobe N, Goto S, Inaguma Y, Ohshima K. Immunoreactive $\alpha$ Acrystallin in rat non-lenticular tissues is detected with a sensitive immunoassay system. Biochimica et Biophysica Acta 1991;1080 173-180.

[90] Kato K, Shinohara H, Kurobe N, Inaguma Y, Shimizu K, Ohshima K. Tissue distribution and developmental profiles of immunoreactive $\alpha \mathrm{B}$-crystallin in the rat determined with a sensitive immunoassay system. Biochimica et Biophysica Acta 1991;1074(1) 201-208.

[91] Srinivasan AN, Nagimeni CN, Bhat SP. $\alpha$ A-Crystallin is expressed in non-ocular tissues. Journal of Biological Chemistry 1992;267(32) 23337-23341.

[92] van Rijk AF, Bloemendal H. Alpha-B-crystallin in neuropathology. Ophthalmologica 2000;214 7-12. 
[93] Carver JA, Rekas A, Thorn DC, Wilson MR. Small heat-shock proteins and clusterin: intra- and extracellular molecular chaperones with a common mechanism of action and function? IUBMB Life 2003;55(12) 661-668.

[94] Carver JA, Guerreiro N, Nicholls KA, Truscott RJW. On the interaction of $\alpha$-crystallin with unfolded proteins. Biochimica et Biophysica Acta 1995 June 28, 1995;1252 251-260.

[95] Treweek TM, Lindner RA, Mariani M, Carver JA. The small heat-shock chaperone protein, $\alpha$-crystallin, does not recognise stable molten globule states of cytosolic proteins. Biochimica et Biophysica Acta 2000 May 31, 2000;1481 175-188.

[96] Lindner RA, Treweek TM, Carver JA. The molecular chaperone $\alpha$-crystallin is in kinetic competition with aggregation to stabilize a monomeric molten-globule form of $\alpha$ lactalbumin. Biochemical Journal 2001;354(1) 79-87.

[97] van Montfort RLM, Slingsby C, Vierling E. Structure and function of the small heat shock protein/alpha-crystallin family of molecular chaperones. Advances in Protein Chemistry 2001;59 105-156.

[98] Haley DA, Bova MP, Huang Q-L, Mchaourab HS, Stewart PL. Small heat-shock protein structures reveal a continuum from symmetric to variable assemblies. Journal of Molecular Biology 2000;298 261-272.

[99] Horwitz J. Review: Alpha-crystallin. Experimental Eye Research 2003;76 145-153.

[100] Lindner RA, Kapur A, Mariani M, Titmuss SJ, Carver JA. Structural alterations of $\alpha-$ crystallin during its chaperone action. European Journal of Biochemistry 1998;258 170-183.

[101] Lindner RA, Carver JA, Ehrnsperger M, Buchner J, Esposito G, Behlke J, Lutsch G, Kotlyarov A, Gaestel M. Mouse Hsp25, a small heat shock protein. The role of its Cterminal extension in oligomerization and chaperone action. European Journal of Biochemistry 200028 Jan 2000;267 1923-1932.

[102] Sobott F, Benesch JLP, Vierling E, Robinson CV. Subunit exchange of multimeric protein complexes. Journal of Biological Chemistry 2002;277(41) 38921-38929.

[103] Treweek TM, Morris AM, Carver JA. Intracellular protein unfolding and aggregation: The role of small heat-shock chaperone proteins. Australian Journal of Chemistry 2003;56 357-367.

[104] Bova MP, Mchaourab HS, Han Y, Fung BK-K. Subunit exchange of small heat shock proteins. Journal of Biological Chemistry 2000;275(2) 1035-1042.

[105] Bova MP, Huang Q-L, Ding L, Horwitz J. Subunit exchange, conformational stability, and chaperone-like function of the small heat shock protein 16.5 from Methanococcus jannaschii. Journal of Biological Chemistry 2002;277(41) 38468-38475.

[106] Carver JA, Rekas A, Thorn DC, Wilson MR. Small heat shock proteins and clusterin: intra- and extracellular molecular chaperones with a common mechanism of action and function? IUBMB Life 2003;55 661-668.

[107] Morr CV, Josephson RV. Effect of calcium, N-ethylmaleimide and casein upon heatinduced whey protein aggregation. Journal of Dairy Science 1968;51 1349-1355.

[108] Kenkare DB, Morr CV, Gould IA. Factors affecting the heat aggregation of proteins in selected skim milk sera. Journal of Dairy Science 1964;47 947-952.

[109] Bhattacharyya J, Das KP. Molecular chaperone-like properties of an unfolded protein, as-casein. Journal of Biological Chemistry 1999;274(22) 15505-15509. 
[110] Zhang X, Fu X, Zhang H, Liu C, Jiao W, Chang Z. Chaperone-like activity of $\beta$-casein. International Journal of Biochemistry and Cell Biology 2005;37 1232-1240.

[111] Barzegar A, Yousefi R, Sharifzadeh A, Dalgalarrondo M, Saboury AA, Haertle T, Moosavi-Movahedi AA. Chaperone activities of bovine and camel $\beta$-caseins: Importance of their surface hydrophobicity in protection against alcohol dehydrogenase aggregation. International Journal of Biological Macromolecules 2008;42(4) 392-399.

[112] Yong YH, Foegeding EA. Effects of caseins on thermal stability of bovine $\beta$ lactoglobulin. Journal of Agricultural and Food Chemistry 2008;56(21) 10352-10558.

[113] Matsudomi N, Kanda Y, Yoshika Y, Moriwaki H. Ability of $\alpha$ S-casein to suppress the heat aggregation of ovotransferrin. Journal of Agricultural and Food Chemistry 2004;52 $4882-4886$.

[114] Koudelka T, Hoffmann P, Carver JA. Dephosphorylation of $\alpha$ s- and $\beta$-caseins and its effect on chaperone activity: a structural and functional investigation. Journal of Agricultural and Food Chemistry 2009;57(13) 5956-5964.

[115] Ptitsyn OB. Protein folding: Hypotheses and experiments. Journal of Protein Chemistry 1987;6 273-293.

[116] Gilmanshin RI, Ptitsyn OB. An early intermediate of refolding $\alpha$-lactalbumin forms within 20 ms. FEBS Letters 1987;223(2) 327-329.

[117] Baum J, Dobson CM, Evans MC, Hanley C. Characterization of a partly folded protein by NMR methods: studies on the molten globule state of guinea pig $\alpha$-lactalbumin. Biochemistry 1989;28(1) 7-13.

[118] Lala AK, Kaul P. Increased exposure of hydrophobic surfaces in molten globule state of $\alpha$-lactalbumin: Fluorescence and hydrophobic photolabeling studies. Journal of Biological Chemistry 1992;267(28) 19914-19918.

[119] Alexandrescu AT, Evans MC, Pitkeathly M, Baum J, Dobson CM. Structure and dynamics of the acid-denatured molten globule state of $\alpha$-lactalbumin: A twodimensional NMR study. Biochemistry 1993;32 1707-1718.

[120] Chyan C-L, Wormald C, Dobson CM, Evans MC, Baum J. Structure and stability of the molten globule state of guinea-pig $\alpha$-lactalbumin: A hydrogen exchange study. Biochemistry 1993;32 5681-5691.

[121] Dobson CM. Protein folding. Solid evidence for molten globules. Current Biology 1994;4(7) 636-640.

[122] Carver JA, Lindner RA, Lyon C, Canet D, Hernandez H, Dobson CM, Redfield C. The interaction of the molecular chaperone $\alpha$-crystallin with unfolding a-lactalbumin: A structural and kinetic spectroscopic study. Journal of Molecular Biology 2002;318 815-827.

[123] Farrell HMJ, Qi PX, Brown EM, Cooke PH, Tunick MH, Wickham ED, Unruh JJ. Molten globule structures in milk proteins: implications for potential new structurefunction relationships. Journal of Dairy Science 2002;85 459-471.

[124] Raman B, Rao CM. Chaperone-like activity and quaternary structure of $\alpha$-crystallin. Journal of Biological Chemistry 1994;269(44) 27264-27268.

[125] Raman B, Ramakrishna T, Rao CM. Temperature dependent chaperone-like activity of $\alpha$-crystallin. FEBS Letters 1995;365(2-3) 133-136.

[126] Treweek TM, Rekas A, Lindner RA, Walker MJ, Aquilina JA, Robinson CV, Horwitz J, Perng MD, Quinlan RA, Carver JA. R120G $\alpha$ B-crystallin promotes the unfolding 
of reduced $\alpha$-lactalbumin and is inherently unstable. FEBS Journal 2005;272(3) 711724.

[127] Das BK, Surewicz WK. Temperature-induced exposure of hydrophobic surfaces and its effect on the chaperone activity of $\alpha$-crystallin. FEBS Letters 1995;369(2-3) 321-325.

[128] Bhattacharyya J, Das KP. Alpha-crystallin does not require temperature activation for its chaperone-like activity. Biochemistry and Molecular Biology International. 1998;46(2) 249-258.

[129] Guha S, Manna TK, Das KP, Bhattacharyya J. Chaperone-like activity of tubulin. Journal of Biological Chemistry 1998;273 30077-30080.

[130] Poon S, Rybchyn MS, Easterbrook-Smith SB, Carver JA, Pankhurst GJ, Wilson MR. Mildly acidic $\mathrm{pH}$ activates the extracellular molecular chaperone clusterin. Journal of Biological Chemistry 2002;277(42) 39532-39540.

[131] McMeekin TL, Polis BD. Milk Proteins. Advances in Protein Chemistry. 1949;5 202-228.

[132] Waugh DF. Formation and structure of casein micelles. In: McKenzie HA (ed.) Milk Proteins: Chemistry and Molecular Biology. New York: Academic Press; 1971. p17-40.

[133] Koretz JF, Doss EW, LaButti JN. Environmental factors influencing the chaperone-like activity of a-crystallin. International Journal of Biological Macromolecules 1998;22(3-4) 283-294.

[134] Brockwell $\mathrm{CH}$. The effect of $\mathrm{pH}$ on the structure and function of $\alpha$-crystallin and cyclodextrins as artificial molecular chaperones. PhD thesis. University of Adelaide; 2009.

[135] Devlin GL, Carver JA, Bottomley SP. The selective inhibition of serpin aggregation by the molecular chaperone, $\alpha$-crystallin, indicates a nucleation-dependent specificity. Journal of Biological Chemistry 2003;278(49) 48644-48650.

[136] Poon S, Treweek TM, Wilson MR, Easterbrook-Smith SB, Carver JA. Clusterin is an extracellular chaperone that specifically interacts with slowly aggregating proteins on their off-folding pathway. FEBS Letters 2002;513(2-3) 259-266.

[137] Ghahghaei A. The chaperone action of $\alpha$-crystallin. PhD thesis. University of Wollongong; 2006.

[138] Manna T, Sarkar T, Poddar A, Roychowdhury M, Das KP, Bhattacharyya B. Chaperone-like activity of tubulin. Binding and reactivation of unfolded substrate enzymes. Journal of Biological Chemistry 2001;276 39742-39747.

[139] Haslbeck M, Buchner J. Chaperone function of sHsps. In: Arrigo AP, Muller WEG. (eds.) Small stress proteins. Berlin: Springer-Verlag; 2002.

[140] Stromer T, Ehrnsperger M, Gaestel M, Buchner J. Analysis of the interaction of small heat shock proteins with unfolding proteins. Journal of Biological Chemistry 2003;278(20) 18015-18021.

[141] Friedrich KL, Giese KC, Buan NR, Vierling E. Interactions between small heat shock protein subunits and substrate in small heat shock protein-substrate complexes. Journal of Biological Chemistry 2004;279(2) 1080-1089.

[142] Muchowski PJ, Hays LG, Yates JRI, Clark JI. ATP and the core " $\alpha$-crystallin" domain on the small heat-shock protein $\alpha$ B-crystallin. Journal of Biological Chemistry 1999;274(42) 30190-30195.

[143] Haley DA, Bova MP, Huang Q-L, Mchaourab HS, Stewart PL. Small heat-shock protein structures reveal a continuum from symmetric to variable assemblies. Journal of Molecular Biology 2000;298 261-272. 
[144] Regini JW, Ecroyd H, Meehan S, Bremmell K, Clarke MJ, Lammie D, Wess T, Carver JA. The interaction of unfolding $\alpha$-lactalbumin and malate dehydrogenase with the molecular chaperone $\alpha \mathrm{B}$-crystallin: a light and X-ray scattering investigation. Molecular Vision 2010;16 2446-2456.

[145] Farahbakhsh ZT, Huang QL, Ding LL, Altenbach C, Steinhoff HJ, Horwitz J, Hubbell WL. Interaction of $\alpha$-crystallin with spin-labeled peptides. Biochemistry 1995;34(2) 509-516.

[146] Alaimo MH, Wickham ED, Farrell HMJ. Effect of self-association of $\alpha$ S1-casein and its cleavage fractions $\alpha$ S1-casein(136-196) and $\alpha$ S1-casein(1-197), on aromatic circular dischroism spectra: comparison with predicted models. Biochimica et Biophysica Acta 1999;1431 395-409.

[147] Schmidt DG. Association of caseins and casein micelle structures. In: Fox PF. (ed.) Developments in Dairy Chemistry - 1. Proteins. London: Elsevier Applied Science Publishers; 1982. p161-86.

[148] Kudva YC, Hiddinga HJ, Butler PC, Mueske CS, Eberhardt NL. Small heat shock proteins inhibit in vitro A beta(1-42) amyloidogenesis. FEBS Letters 1997;416(1) 117-121.

[149] Stege GJ, Renkawek K, Overkamp PS, Verschuure P, van Rijk AF, Reijnen-Aalbers A, Boelens WC, Bosman GJ, de Jong WW. The molecular chaperone $\alpha \mathrm{B}$-crystallin enhances amyloid $\beta$ neurotoxicity. Biophysical and Biochemical Research Communications 1999;262(1) 152-156.

[150] Hatters DM, Lindner RA, Carver JA, Howlett GJ. The molecular chaperone, $\alpha$ crystallin, inhibits amyloid formation by Apolipoprotein C-II. Journal of Biological Chemistry 2001;276 33755-33761.

[151] Rekas A, Adda CG, Aquilina JA, Barnham KJ, Sunde M, Galatis D, Williamson NA, Masters CL, Anders RF, Robinson CV, Cappai R, Carver J. Interaction of the molecular chaperone $\alpha B$-crystallin with a-synuclein: Effects on amyloid fibril formation and chaperone activity. Journal of Molecular Biology 2004;340 1167-1183.

[152] Ecroyd H, Koudelka T, Thorn DC, Williams DM, Devlin G, Hoffmann P, Carver JA. Dissociation from the oligomeric state is the rate-limiting step in fibril formation by $\mathrm{\kappa}$ casein. Journal of Biological Chemistry 2008;283(14) 9012-9022.

[153] Das BK, Surewicz WK. On the substrate specificity of $\alpha$-crystallin as a molecular chaperone. Biochemical Journal 1995;311(2) 367-370.

[154] Haslbeck M, Walke S, Stromer T, Ehrnsperger M, White HE, Chen S, Saibil HR, Buchner J. Hsp26: a temperature-regulated chaperone. EMBO Journal 1999;18(23) 6744-6751.

[155] Carver JA, Lindner RA. NMR spectroscopy of $\alpha$-crystallin. Insights into the structure, interactions and chaperone action of small heat-shock proteins. International Journal of Biological Macromolecules 1998;22 197-209.

[156] Jakob U, Gaestel M, Engel K, Buchner J. Small heat shock proteins are molecular chaperones. Journal of Biological Chemistry 1993;268(3) 1517-1520.

[157] Merck KB, Groenen PJ, Voorter CE, de Haard-Hoekman WA, Horwitz J, Bloemendal $\mathrm{H}$, de Jong WW. Structural and functional similarities of bovine $\alpha$-crystallin and mouse small heat-shock protein. A family of chaperones. Journal of Biological Chemistry 1993;268(2) 1046-1052. 